Sheffield

Hallam

University

Centre for

Regional Economic

and Social Research

\title{
Hitting the poorest places hardest \\ The local and regional impact of welfare reform
}

Christina Beatty Steve Fothergill 


\title{
HITTING THE POOREST PLACES HARDEST
}

The local and regional impact of welfare reform

\author{
Christina Beatty and Steve Fothergill \\ Centre for Regional Economic and Social Research \\ Sheffield Hallam University
}

April 2013

DOI: 10.3351/cresr.2017.6378897426

The research on which the report is based was funded by Sheffield Hallam University, by the Scottish Parliament and by the Financial Times (by a grant from the Pulitzer Centre on Crisis Reporting in Washington). The views expressed are those of the authors alone. 


\section{Note on the authors}

Christina Beatty is a Professor in the Centre for Regional Economic and Social Research (CRESR) at Sheffield Hallam University, and a statistician by background.

Steve Fothergill is also a Professor within CRESR at Sheffield Hallam University, and an economist by background.

Both authors have an extensive record of research and publication on local and regional trends across the UK, and on the benefits system. Their recent reports include Incapacity benefit reform: the local, regional and national impact and The Real Level of Unemployment 2012. 


\section{Key points}

- When the present welfare reforms have come into full effect they will take nearly $£ 19 b n$ a year out of the economy. This is equivalent to around $£ 470$ a year for every adult of working age in the country.

- The biggest financial losses arise from reforms to incapacity benefits ( $£ 4.3 b n$ a year), changes to Tax Credits (£3.6bn a year) and the 1 per cent up-rating of most working-age benefits (£3.4bn a year).

- The Housing Benefit reforms result in more modest losses - an estimated £490m a year arising from the 'bedroom tax' for example - but for the households affected the sums are nevertheless still large.

- Some households and individuals, notably sickness and disability claimants, will be hit by several different elements of the reforms.

- The financial impact of the reforms, however, varies greatly across the country. At the extremes, the worst-hit local authority areas lose around four times as much, per adult of working age, as the authorities least affected by the reforms.

- Britain's older industrial areas, a number of seaside towns and some London boroughs are hit hardest. Much of the south and east of England outside London escapes comparatively lightly.

- Blackpool, in North West England, is hit worst of all - an estimated loss of more than $£ 900$ a year for every adult of working age in the town.

- The three regions of northern England alone can expect to lose around £5.2bn a year in benefit income.

- As a general rule, the more deprived the local authority, the greater the financial hit.

- A key effect of the welfare reforms will be to widen the gaps in prosperity between the best and worst local economies across Britain. 


\section{HITTING THE POOREST PLACES HARDEST \\ The local and regional impact of welfare reform}

\section{Scope and purpose of the report}

The UK Government is implementing welfare reforms that apply to all parts of the country. The impact of the reforms, however, will vary enormously from place to place, not least because benefit claimants are so unevenly spread across Britain.

It is only reasonable to expect that the welfare reforms will hit the poorest parts of Britain hardest. After all, one of the reasons why some places are so poor is that they have so many people claiming benefits. On the other hand, the welfare reforms extend well beyond just those who are out-of-work to include large swathes of the employed population as well. So just how big will the impact be on different places? And just how much harder will the reforms hit the poorer parts of Britain than more prosperous areas?

These are the questions to which this report provides answers. It provides figures not just for Great Britain as a whole and for each of its constituent 379 local authority areas ${ }^{1}$. The figures cover the number of households or individuals affected, and the total financial loss to each local area. In the report itself a limited number of statistics are presented on the impact of each of the individual benefit reforms in each local authority. The full dataset, by benefit by authority, can however be accessed at:

http://www.shu.ac.uk/research/cresr/sites/shu.ac.uk/files/Welfare Reform.xls

All the figures presented in the report are estimates, but in every case they are deeply rooted in official statistics - for example in the Treasury's own estimates of the financial savings, the government's Impact Assessments, and benefit claimant data.

Welfare reform is a deeply contentious issue and in documenting the impacts the report does not attempt to comment on the merits of each of the reforms. However, it is important that the impact on different places is fully exposed because this is a key dimension that is too often overlooked. The impact on different places is also one of the yardsticks by which the reforms should be judged.

\footnotetext{
${ }^{1}$ Unitary authorities and district councils, excluding Isles of Scilly
} 


\section{The welfare reforms}

The figures presented in the report cover all the major welfare reforms that are currently underway. In brief, these are:

\section{Housing Benefit - Local Housing Allowance}

Changes to the rules governing assistance with the cost of housing for low-income households in the private rented sector. The new rules apply to rent levels, 'excess' payments, property size, age limits for sole occupancy, and indexation for inflation.

\section{Housing Benefit - Under-occupation}

New rules governing the size of properties for which payments are made to working age claimants in the social rented sector (widely known as the 'bedroom tax')

\section{Non-dependant deductions}

Increases in the deductions from Housing Benefit, Council Tax Benefit and other income-based benefits to reflect the contribution that non-dependant household members are expected to make towards the household's housing costs

\section{Household benefit cap}

New ceiling on total payments per household, applying to the sum of a wide range of benefits for working age claimants

\section{Council Tax Benefit}

Reductions in entitlement of working age claimants arising from 10 per cent reduction in total payments to local authorities

\section{Disability Living Allowance}

Replacement of DLA by Personal Independence Payments (PIP), including more stringent and frequent medical tests, as the basis for financial support to help offset the additional costs faced by individuals with disabilities

\section{Incapacity benefits}

Replacement of Incapacity Benefit and related benefits by Employment and Support Allowance (ESA), with more stringent medical tests, greater conditionality and timelimiting of non-means tested entitlement for all but the most severely ill or disabled

\section{Child Benefit}

Three-year freeze, and withdrawal of benefit from households including a higher earner

\section{Tax Credits}

Reductions in payment rates and eligibility for Child Tax Credit and Working Families Tax Credit, paid to lower and middle income households

\section{1 per cent up-rating}

Reduction in annual up-rating of value of most working-age benefits 
A fuller description of each of these reforms, including the timing of implementation and the expected savings to the Exchequer, is contained in the appendix to the report.

The vast majority of these welfare reforms have been initiated by the present Coalition government in Westminster, notably but not exclusively through the Welfare Reform Act 2012. Some of the incapacity benefit reforms, however, are Labour measures that pre-date the 2010 general election but are only now taking full effect. They have been included here, alongside the Coalition's reforms, to provide a comprehensive view of the impact of the reforms that are currently underway.

The figures the report presents show the impact when the reforms have come into full effect. This is important because some of the reforms, particularly those affecting incapacity and disability benefits, are being implemented in stages over a number of years. In most cases, the figures show the expected impact in the 2014-15 financial year ${ }^{2}$.

A close observer of the list of reforms will note a number of apparent omissions. The most significant of these is Universal Credit, which is scheduled to replace just about all meanstested working age benefits and is arguably the single biggest reform of all. There are three reasons for omitting Universal Credit:

- Universal Credit is best understood as a repackaging of existing benefits. It introduces for the first time a consistent benefit withdrawal rate, intended to ensure that claimants are always financially better off in work, but the rules governing eligibility are essentially carried over from the existing benefits it replaces.

- Unlike the other welfare reforms covered here, Universal Credit is not expected to result in a net reduction in benefit entitlement. At the level of the individual or household there will winners and losers but on balance Universal Credit is expected to result in slightly higher expenditure, particularly as transitional relief will be available to existing claimants transferring across.

- Most of the impact of Universal Credit will be felt well beyond 2015. Its introduction begins in 2013 only in a small number of pilot areas and only for new claimants. The full impact is unlikely before 2018 .

Additionally, without local-level household data, which is not available, it is extremely difficult to model the local impact of Universal Credit. That said, it should be noted that the intention to pay the housing element of Universal Credit to tenants, rather than direct to landlords, is a major cause of concern in the social housing sector.

Two further omissions are worth noting:

\footnotetext{
${ }^{2}$ The exceptions are the DLA reforms, which will not impact fully until 2017-18, and the wider application of means testing to ESA and the 1 per cent up-rating, both of which do not impact fully until 2015-16.
} 
- Income Support for lone parents. The qualifying age of the youngest child has been reduced from under 7 to under 5 . The effect is to transfer the lone parent from Income Support to Jobseeker's Allowance at the same payment rate.

- $\quad$ RPI to CPI for benefits up-rating. This was introduced from 2011-12 but is really part of a much wider accounting reform, including for example all public service pensions.

When fully implemented, the welfare reforms covered in this report are expected to save the UK Treasury almost £19bn a year.

\section{Measuring the impacts}

The data sources and methods underpinning the estimates are set out in full in the appendix to the report.

The government has in most cases not produced estimates of the local impact of the reforms. It does however publish a range of statistics that allow the local impact to be estimated. This information includes:

- HM Treasury estimates of the overall financial saving arising from each element of the reforms, published in the Budget or in the government's Autumn Statement. The estimates in the report are fully consistent with these Treasury figures ${ }^{3}$.

- The Impact Assessment and (where available) Equality Impact Assessment that government departments publish for each element of the reforms ${ }^{4}$

- Benefit claimant numbers and expenditure, by local authority, published by DWP and HMRC

- Additional official statistics - for example on median earnings by local authority to help calibrate the impact of the withdrawal of Child Benefit

- DWP evidence from pilot schemes, in the context of the incapacity benefit reforms

As far as possible, for each benefit the figures presented in the report take account of the overall financial saving to the UK Exchequer, the distribution of benefit claimants between local authorities, and the extent to which claimants in each local authority are likely to be affected by the reforms.

\footnotetext{
${ }^{3}$ The estimates of the impact of the reforms to incapacity benefits, DLA and Council Tax Benefit are subject to further detailed adjustment - see appendix.

${ }^{4}$ Following official practice in the Impact Assessments, the estimates in the present report make no allowance for the small share of the financial impact falling on Northern Ireland. The effect is to slightly overstate the impact on other parts of Great Britain, bearing in mind that Northern Ireland accounts for 3 per cent of the UK population.
} 
In comparing the impact on different areas, the report looks in particular at the financial loss per adult of working age ${ }^{5}$. A focus on adults of working age (16-64) is appropriate because the welfare reforms impact almost exclusively on this group. By contrast, benefit claimants of pensionable age are essentially unaffected ${ }^{6}$.

Some of the welfare reforms focus on households - the reforms to Housing Benefit for example. Others - the reforms to incapacity benefits for example - are about the entitlement of individuals. Additionally, several of the reforms are likely to impact simultaneously on the same households and/or individuals. It is possible to estimate how many people are affected by each element of the reforms, and how much they lose. The financial losses can be added together but to avoid counting the same people twice the number of households/individuals affected cannot be summed to an overall total.

Finally, in estimating the impact of the welfare reforms the report holds all other factors constant. What this means in practice is that it makes no assumptions about the growth of the economy or about future levels of employment and unemployment.

UK ministers take the view that the welfare reforms will increase the financial incentives to take up employment and because more people will look for work more people will find work. This assumes, of course, that extra labour supply leads to extra labour demand from employers. Whether labour markets really do work in this way, especially at times of recession or low growth, or in places where the local economy is relatively weak, is a moot point and one that many economists would contest. Some individuals will undoubtedly find work to compensate for the loss of benefit income but whether the overall level of employment will be any higher as a result is questionable. More often than not, they will simply fill vacancies that would have gone to other jobseekers. So the figures in this report do not assume that loss of income from benefits will wholly or in part be replaced by additional income from employment.

\section{The impact of the reforms}

\section{Overall national impact}

Table 1 shows the estimated impact of the welfare reforms across Great Britain as a whole. As noted earlier, when the reforms have come into full effect it is estimated that they will reduce spending by almost $£ 19 \mathrm{bn}$ a year. This represents around $£ 470$ a year for every adult of working age in the country.

The individual welfare reforms vary greatly in the scale of their impact, in the number of individuals or households affected, and in the intensity of the financial loss imposed on those

\footnotetext{
${ }^{5}$ In Scotland's case, where only a limited range of 2011 Census data has so far been published, the working age population figures for each authority are an estimate based on the overall population from the 2011 Census and the age distribution of the population in 2010 from the mid-year population estimates. In the rest of Britain the figures are all taken from the 2011 Census.

${ }^{6}$ The main exceptions are a small minority (around 5\%) of Housing Benefit recipients in the private rented sector, affected by the reforms to Local Housing Allowance, and a small number of adults of pensionable age who receive Child Benefit.
} 
Table 1: Overall impact of welfare reforms by $2014 / 15$

\begin{tabular}{|c|c|c|c|c|c|}
\hline & $\begin{array}{c}\text { No of } \\
\text { h'holds/individuals } \\
\text { affected }\end{array}$ & $\begin{array}{l}\text { Estimated } \\
\text { loss } \\
\text { £m p.a. }\end{array}$ & $\begin{array}{l}\text { Average loss per } \\
\text { affected } \\
\text { h'hold/individual } \\
£ \text { p.a. }\end{array}$ & $\begin{array}{c}\text { No. of } \\
\text { h'holds/individuals } \\
\text { affected } \\
\text { per } 10,000\end{array}$ & $\begin{array}{l}\text { Loss per } \\
\text { working age adult } \\
£ \text { p.a. }\end{array}$ \\
\hline Incapacity benefits ${ }^{(1)(3)}$ & $1,250,000$ & 4,350 & 3,480 & 310 & 110 \\
\hline Tax Credits & $4,500,000$ & 3,660 & 810 & 1,750 & 90 \\
\hline 1 per cent uprating ${ }^{(3)}$ & n.a. & 3,430 & n.a. & n.a. & 85 \\
\hline Child Benefit & $7,600,000$ & 2,845 & 370 & 2,960 & 70 \\
\hline Housing Benefit: LHA & $1,350,000$ & 1,645 & 1,220 & 520 & 40 \\
\hline Disability Living Allowance ${ }^{(1)(2)}$ & 500,000 & 1,500 & 3,000 & 130 & 40 \\
\hline Housing Benefit: 'bedroom tax' & 660,000 & 490 & 740 & 260 & 10 \\
\hline Non-dependant deductions & 300,000 & 340 & 1,130 & 120 & 10 \\
\hline Council Tax Benefit & $2,450,000$ & 340 & 140 & 950 & 10 \\
\hline Household benefit cap & 56,000 & 270 & 4,820 & 20 & 5 \\
\hline Total & n.a. & 18,870 & n.a. & n.a. & 470 \\
\hline
\end{tabular}

\footnotetext{
(1) Individuals affected; all other data refers to households

(2) By 2017/18

(3) By $2015 / 16$

Source: Sheffield Hallam estimates based on official data
} 
affected. A great deal of media coverage has focussed on, for example, the 'bedroom tax' and the overall household benefit cap. In fact, the biggest financial impact comes from the reform of incapacity benefits - an estimated reduction in spending of more than $£ 4$.3bn a year. Changes to Tax Credits and the 1 per cent up-rating of most working-age benefits, taking effect from April 2013, also account for substantial sums - £3.6bn and £3.4bn respectively.

Child Benefit changes affect the largest number of households - some $7.6 \mathrm{~m}$. This is because the three-year freeze in Child Benefit rates up to April 2014 (instead of up-rating with inflation) impacts on all recipients.

The household benefit cap, by contrast, impacts on many fewer households - an estimated 56,000 - but the average financial loss for each of these households is relatively large.

Sickness and disability claimants can also expect to be hit hard. The individuals adversely affected by the incapacity benefit reforms can expect to lose an average of $£ 3,500$ a year, and those losing out as a result of the changeover from Disability Living Allowance to Personal Independence Payments by an average of $£ 3,000$ a year. Often these will be the same individuals: most DLA claimants of working age are out-of-work on incapacity benefits and in both cases the groups most exposed to benefit reductions are those with less severe disabilities or health problems.

The same individuals may also find that they encounter reductions in Housing Benefit entitlement. The overall reductions in Housing Benefit are estimated to be more than $£ 1.6 \mathrm{bn}$ for those in the private rented sector (affected by LHA reforms), £490m for those in the social rented sector (affected by the 'bedroom tax') and £340m by higher deductions for nondependants (which mostly impact on Housing Benefit). The losses for the households affected - often $£ 1,000$ a year - are large.

The changes to Council Tax Benefit hit large numbers of households - approaching $2.5 \mathrm{~m}$, though none in Scotland or Wales (where the devolved administrations have chosen not to pass on the reductions). The average financial loss per household - and estimated $£ 140 \mathrm{a}$ year - is more modest than the other benefit cuts, though still likely to be hard to find in many cases.

\section{Impact by local authority}

Figure 1 shows the overall impact of the welfare reforms by local authority district. The measure used here is the financial loss per adult of working age so the data measures the intensity of the financial impact in each area.

The overall impact of the welfare reforms presents a complex picture, not least because different reforms impact on places in different ways. Nevertheless, the map shows clear patterns that will be readily recognisable to anyone with a solid understanding of the geography of Britain. Three types of area are hit hardest: 
Figure 1: Overall financial loss arising from welfare reform by $2014 / 15^{(1)}$, by local authority

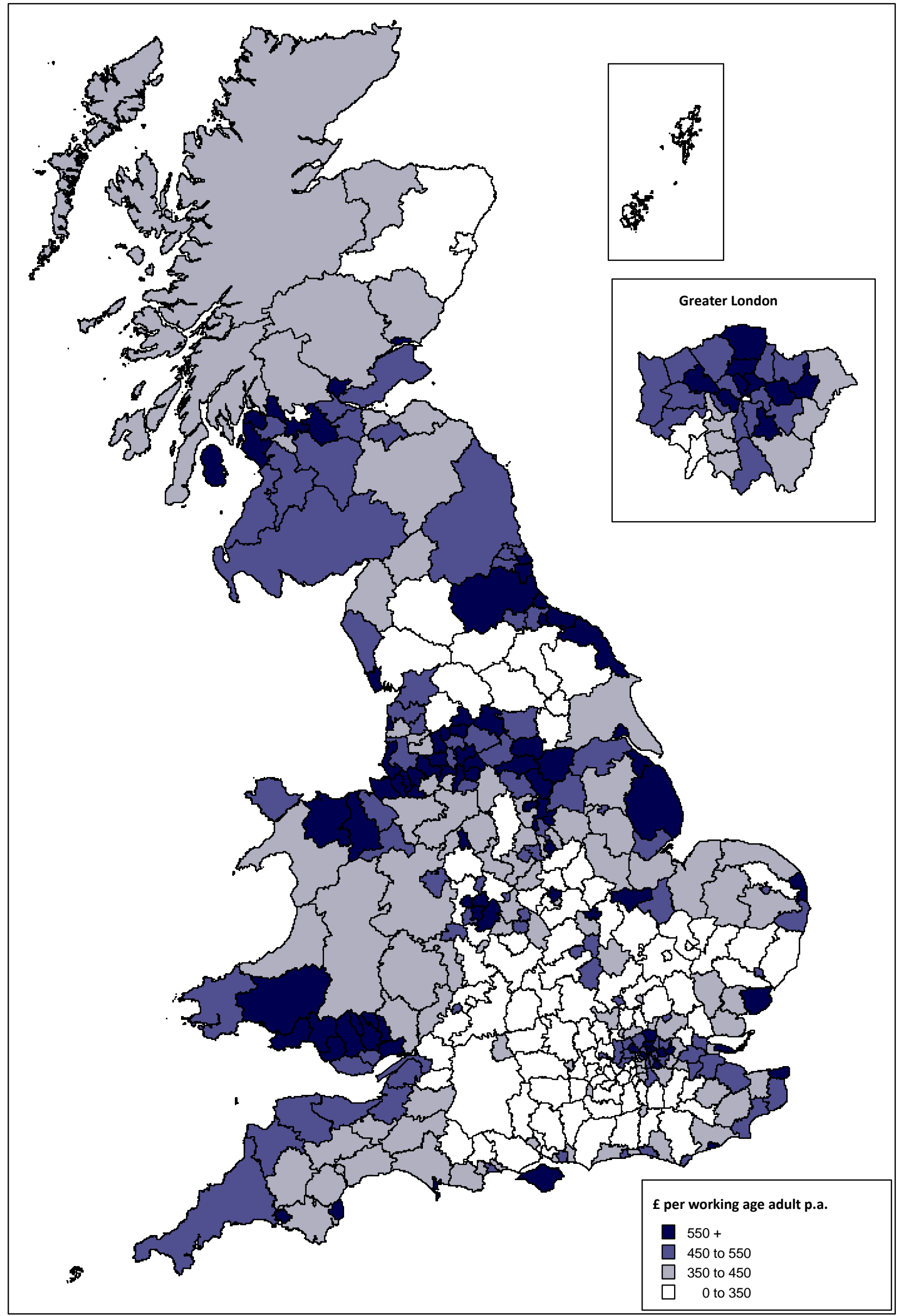

${ }^{(1)}$ Except DLA by $2017 / 18$, incapacity benefits and $1 \%$ uprating by $2015 / 16$ Source: Sheffield Hallam estimates based on official data 
- The older industrial areas of England, Scotland and Wales. These include substantial parts of North West and North East England, the South Wales Valleys and the Glasgow area in Scotland. Older industrial areas account for the largest proportion of the worst-hit places.

- A number of seaside towns. These include Blackpool, Torbay, Hastings, Great Yarmouth and Thanet (which includes Margate). Not all seaside resorts are badly hit but this group - which includes several of the least prosperous - matches the impact on older industrial areas.

- Some London boroughs. These include not just those that have traditionally been identified as 'deprived' (eg Hackney) but also boroughs such as Westminster and Brent.

At the other end of the spectrum, a substantial part of southern England outside London is much less acutely affected by the welfare reforms. A number of rural areas in northern England, including most of North Yorkshire and parts of Cumbria, plus the Aberdeen area in Scotland, also escape relatively lightly.

\section{The worst affected places}

To underline the disparities, Table 2 lists the 50 local authority districts worst affected by the reforms, measured on a per capita basis, and contrasts this with the 20 least affected.

At the very top of the list comes Blackpool, the famous seaside resort in North West England, where the average loss per working age adult is estimated to be $£ 914$ a year. Blackpool tops the list for a number of reasons. It has a high proportion of adults of working age out-of-work on benefits, including one of the highest incapacity claimant rates in the country. But unlike most of older industrial Britain, which shares the high rates out-of-work on benefits, Blackpool has a particularly high proportion of households (including out-of-work households) living in the private-rented sector, who are badly exposed to the reductions in the Local Housing Allowance element of Housing Benefit. It is also worth noting that Blackpool borough itself (to which the figures refer) is something of an 'inner urban area' within a larger built-up area that also includes Lytham St Anne's and Fleetwood.

Westminster, at number two on the list, is the glaring exception to the general rule that the poorest parts of Britain are hit hardest. But there are special factors at work. One is the possibility that the 2011 Census population figures, used here, significantly under-estimate the local population, as Westminster City Council has claimed ${ }^{7}$, in which case the benefit losses in this table are being spread across too few people and the true figure could be $£ 100$ per head lower. But also the extremely high rents in Westminster mean that, more than anywhere else in Britain, the Housing Benefit reforms and the household benefit cap lead to

\footnotetext{
${ }^{7}$ The problem lies with possible under-recording by the Census in areas where there is a highly transient population and difficulty in contacting households. Westminster is likely to be the extreme case in this regard.
} 


\section{Loss per \\ working \\ age adult \\ E p.a.}

\section{TOP 50 DISTRICTS}

1. Blackpool

2. Westminster

3. Knowsley

4. Merthyr Tydfil

5. Middlesbrough

6. Hartlepool

7. Torbay

8. Liverpool

9. Blaenau Gwent

10. Neath Port Talbot

11. Hastings

12. Burnley

13. Rochdale

14. Barking and Dagenham

15. Brent

16. Hyndburn

17. Blackburn with Darwen

18. Thanet

19. Stoke-on-Trent

20. Rhondda, Cynon, Taf

21. Hackney

22. Enfield

23. Glasgow

24. Salford

25. Caerphilly

26. Oldham

27. Wirral

28. Haringey

29. St. Helens

30. Inverclyde

31. Barrow-in-Furness

32. Kingston upon Hull

33. Barnsley

34. Tameside

35. South Tyneside

36. Halton

37. Redcar and Cleveland

38. Sunderland

39. Tendring
910

820

800

720

720

710

700

700

700

700

690

690

680

680

680

680

670

670

670

670

670

670

650

640

640

640

640

640

630

630

630

630

630

620

620

620

620

620

620

\section{(cont)}

40. Great Yarmouth 610

41. Sandwell 610

42. Pendle 610

43. Birmingham 610

44. East Lindsey 610

45. Manchester 610

46. West Dunbartonshire 600

47. Mansfield 600

48. Lewisham 600

49. Bridgend 600

50. Bolsover 600

\section{BOTTOM 20 DISTRICTS}

360. Mid Sussex 280

361. East Hampshire 280

362. Waverley 280

363. Cotswold 270

364. Harborough 270

365. Horsham 270

366. Surrey Heath 270

367. Mole Valley 270

368. South Cambridgeshire 270

369. Winchester 270

370. Chiltern 270

371. South Bucks 260

372. Guildford 260

373. South Northamptonshire 260

374. South Oxfordshire 260

375. Rutland 260

376. Wokingham 250

377. Cambridge 250

378. Hart 240

379. City of London 180

(1) Except DLA by 2017/18, incapacity benefits and 1\% up-rating by 2015/16

Source: Sheffield Hallam estimates based on official data 
very large financial losses here. The impact of the other welfare reforms on Westminster is far more modest.

Beyond Blackpool and Westminster, more than two-thirds of the 50 local authority districts worst affected by the reforms could be described as 'older industrial areas' - places like Knowsley (near Liverpool), Liverpool itself, Middlesbrough, Hartlepool, Stoke, Burnley, Glasgow and a succession of Welsh Valleys (Merthyr Tydfil, Blaenau Gwent, Neath Port Talbot, Rhondda Cynon Taf, Caerphilly).

In all these older industrial areas the incapacity benefit reforms, in particular, hit very hard indeed. The reforms to Disability Living Allowance, which often affect the same people, also hit hard here. Incapacity claimant rates in older industrial Britain are far in excess of those in more prosperous parts of the country, not least because of the difficulty that men and women with health problems or disabilities face in finding work in these difficult local labour markets. More generally, the higher reliance on benefits and tax credits in older industrial Britain means that the failure to up-rate with inflation and the reductions to tax credits have a greater impact here.

The City of London emerges as the least affected part of the country, but the City has a very small population and should perhaps be discounted. The other places least affected by the welfare reforms, beginning with Hart district (in Hampshire) and followed by Cambridge and Wokingham (in Berkshire) are exclusively in the south and east of England outside London.

At the extremes, loss per working age adult in the worst affected districts is approaching double the national average ( $\$ 470$ a year). Conversely, the loss in the least affected districts is around half the national average. Or to express the same figures in a different way, there is a four-fold difference in the impact of the welfare reforms between the most and least affected districts.

\section{Largest absolute losses}

Table 3 looks at the same information but from a different angle. It lists the 20 districts where the absolute scale of the financial loss is greatest. This list is inevitably dominated by placed with a large population.

Birmingham (pop. 1,073,000) - Britain's largest local authority by some margin - somewhat inevitably tops this list with a financial loss of nearly $£ 420 \mathrm{~m}$ a year, but this is also in part because its per capita loss (an estimated $£ 607$ per working age adult) is well ahead of the national average. Glasgow (pop. 593,000) comes second with a loss of nearly £270m a year.

Beyond the largest cities, County Durham (pop. 513,000), which covers an extensive and often deprived former mining area, loses nearly $£ 190 \mathrm{~m}$ a year in benefit income. Cornwall (pop. 532,000), which has the lowest GDP per head of all English sub-regions, loses $£ 170 \mathrm{~m}$ a year. The worst affected London borough is Brent (pop. 311,000), which loses just short of $£ 150 \mathrm{~m}$ a year. 


\begin{tabular}{rlcc}
\hline & $\begin{array}{c}\text { Estimated } \\
\text { loss } \\
\text { Em p.a. }\end{array}$ & $\begin{array}{c}\text { Loss per } \\
\text { working age adult } \\
\text { \& p.a. }\end{array}$ \\
\hline 1. & Birmingham & 419 & 610 \\
2. & Glasgow & 269 & 650 \\
3. & Leeds & 232 & 460 \\
4. & Liverpool & 227 & 700 \\
5. & Manchester & 217 & 610 \\
6. & Bradford & 194 & 590 \\
7. & County Durham & 188 & 560 \\
8. & Sheffield & 173 & 470 \\
9. & Cornwall & 171 & 520 \\
10. & Brent & 146 & 680 \\
11. & Bristol & 141 & 480 \\
12. & Kirklees & 140 & 510 \\
13. & Enfield & 136 & 670 \\
14. & Edinburgh & 135 & 400 \\
15. & Westminster & 133 & 820 \\
16. & Croydon & 129 & 540 \\
17. & Wirral & 127 & 640 \\
18. & Newham & 127 & 580 \\
19. & Leicester & 126 & 560 \\
20. & Ealing & 125 & 540 \\
\hline
\end{tabular}

Source: Sheffield Hallam estimates based on official data

Impact by region

Table 4 summarises the impact by region. There is a clear pattern here. The three regions of northern England (North East, North West, Yorkshire) are all hit substantially harder, per working age adult, than the south and east of England. This is principally because they cover so many of the older industrial areas that are badly affected by the reforms. In total, the three northern English regions lose around £5.2bn a year.

London is also hit relatively hard - its loss per working age adult is $£ 50$ a year above the GB average - but this is primarily because the Housing Benefit reforms affecting tenants in the private rented sector, plus the household benefit cap, have a big impact here.

Wales is also hit much harder than the GB average, to much the same extent as northern England and essentially for the same reasons - a concentration of older industrial area badly affected by the incapacity benefit reforms in particular. Scotland escapes a little more lightly, partly because it includes areas of prosperity as well as areas of high worklessness and 
partly because the Housing Benefit reforms impact on a relatively small private rented sector ${ }^{8}$.

One way of looking at the regional differences is that if the five worst affected regions (the three northern English regions plus Wales and London) only experienced the same per capita loss as South East England, total incomes there would be £2.8bn a year higher.

Table 4: Overall impact of welfare reforms by $2014 / 15^{(1)}$ by region

\begin{tabular}{lcc}
\hline & $\begin{array}{c}\text { Estimated } \\
\text { loss } \\
\text { Em p.a. }\end{array}$ & $\begin{array}{c}\text { Loss per } \\
\text { working age adult } \\
\text { \& p.a. }\end{array}$ \\
\hline North West & 2,560 & 560 \\
North East & 940 & 560 \\
Wales & 1,070 & 550 \\
London & 2,910 & 520 \\
Yorkshire and the Humber & 1,690 & 500 \\
West Midlands & 1,740 & 490 \\
Scotland & 1,660 & 480 \\
East Midlands & 1,310 & 450 \\
South West & 1,440 & 430 \\
East & 1,490 & 400 \\
South East & 2,060 & 370 \\
\hline Great Britain & $\mathbf{1 8 , 8 7 0}$ & $\mathbf{4 7 0}$ \\
\hline (1) Except DLA by 2017/18, incapacity benefits and 1\% up-rating by $2015 / 16$ \\
Source: Sheffield Hallam estimates based on official data
\end{tabular}

The relationship to deprivation

There are no surprises in this geography. It is to be expected that welfare reforms will hit hardest in the places where welfare claimants are concentrated, which in turn tend to be the poorest areas. To underline this point, Figure 2 shows the relationship between the impact of the welfare reforms (measured in terms of the loss per adult of working age) and the scale of deprivation in each local authority.

The deprivation measure used here is the share of local neighbourhoods ${ }^{9}$ in the worst 20 per cent nationally. To overcome inconsistencies between the separate deprivation indices for

\footnotetext{
${ }^{8}$ A separate report is available on Scotland. The Impact of Welfare Reform on Scotland, by Christina Beatty and Steve Fothergill, can be accessed on the Scottish Parliament website.

${ }^{9}$ Lower Super Output Areas in England and Wales, datazones in Scotland.
} 
Figure 2: Relationship between impact of welfare reform and deprivation, by local authority



Sources: Sheffield Hallam estimates and Payne and Abel (2012) based on Indices of Deprivation for England, Wales and Scotland 
the constituent counties of the UK, the deprivation figures here are taken from research that re-works the data to produce deprivation statistics for the UK as a whole ${ }^{10}$.

There is a clear and unambiguous relationship: as a general rule, the more deprived the local authority, the greater the financial hit. Overall, for every ten percentage point increase in the share of neighbourhoods in the most deprived 20 per cent, the scale of the financial loss arising from the welfare reforms rises by roughly $£ 60$ per adult of working age.

Blackpool and Westminster are the two most significant outliers above the regression line in Figure 2. This means that the financial loss arising from the welfare reforms is much larger in these two places than deprivation alone would have suggested. The reasons, noted earlier, are Westminster's exceptional exposure to the Housing Benefit reforms affecting the private rented sector and Blackpool's unusual combination of very high worklessness and a very large numbers of Housing Benefit claimants in the private rented sector.

The three east London boroughs of Hackney, Tower Hamlets and Newham are the most significant outliers below the regression line, on the right of the diagram. The share of neighbourhoods in the most deprived 20 per cent nationally is exceptionally high here, though the scale of the financial losses is no larger than in a number of other places with high deprivation.

\section{Concluding remarks}

The impacts of welfare reform are very substantial - an estimated loss of income of approaching $£ 19 \mathrm{bn}$ a year once all the reforms have been fully implemented, or an average of $£ 470$ a year per adult of working age across the whole of Britain. For some of the individuals affected by the changes the loss of income is much, much greater. What is also clear, however, is that the financial losses arising from the reforms will hit some places much harder than others.

At the extremes, as we noted, the loss per head is four times greater in Blackpool than parts of Hampshire. Britain's older industrial areas, a number of seaside towns and some London boroughs are hit hardest. Much of south and east England outside London escapes comparatively lightly. This is an economic geography that overlaps strongly with Britain's political geography: the Coalition government is presiding over national welfare reforms that will impact principally on individuals and communities outside its own heartlands.

As a general rule, the most deprived local authorities across Britain are hit hardest. The loss of benefit income, which is often large, will have knock-on consequences for local spending and thus for local employment, which will in turn will add a further twist to the downward spiral. A key effect of welfare reform will therefore be to widen the gaps in prosperity between the best and worst local economies across the country.

\footnotetext{
${ }^{10}$ These particular statistics have been generated by Rupert Payne and Gary Abel of the University of Cambridge, drawing on the separate Indices of Deprivation for England, Scotland, Wales and Northern Ireland. See R Payne and G Abel (2012) 'UK indices of multiple deprivation - a way to make comparisons across constituent countries easier', Health Statistics Quarterly, vol 53, pp 1-16.
} 


\begin{tabular}{lcccc}
\hline & \multicolumn{4}{c}{ Housing Benefit: LHA } \\
\cline { 2 - 5 } & $\begin{array}{c}\text { No of } \\
\text { h'holds affected }\end{array}$ & $\begin{array}{c}\text { Estimated } \\
\text { loss } \\
\text { Em p.a. }\end{array}$ & $\begin{array}{c}\text { No. of h'holds } \\
\text { affected } \\
\text { per } \mathbf{1 0 , 0 0 0}\end{array}$ & $\begin{array}{c}\text { Financial loss per } \\
\text { working age adult } \\
\text { £ p.a. }\end{array}$ \\
\hline London & 229,000 & 470 & 700 & 85 \\
North East & 64,000 & 70 & 560 & 40 \\
North West & 180,000 & 190 & 600 & 40 \\
South West & 129,000 & 130 & 570 & 40 \\
Yorkshire and the Humber & 121,000 & 120 & 540 & 35 \\
West Midlands & 113,000 & 120 & 490 & 35 \\
South East & 170,000 & 200 & 480 & 35 \\
Wales & 70,000 & 70 & 540 & 35 \\
East Midlands & 89,000 & 90 & 470 & 30 \\
East & 106,000 & 110 & 440 & 30 \\
Scotland & 80,000 & 80 & 340 & 25 \\
\hline Great Britain & $\mathbf{1 , 3 5 0 , 0 0 0}$ & $\mathbf{1 , 6 5 0}$ & $\mathbf{5 2 0}$ & $\mathbf{4 0}$ \\
\hline
\end{tabular}

\begin{tabular}{clc}
\hline WORST AFFECTED & $\begin{array}{c}\text { Loss per } \\
\text { working } \\
\text { age adult } \\
\text { E p.a. }\end{array}$ \\
\hline 1. & Westminster & 390 \\
2. & Kensington and Chelsea & 220 \\
3. & Blackpool & 170 \\
4. & Brent & 165 \\
5. & Brighton and Hove & 125 \\
6. & Hackney & 120 \\
7. & Hastings & 105 \\
8. & Haringey & 105 \\
9. & Lewisham & 105 \\
10. & Camden & 100 \\
11. & Enfield & 100 \\
12. & Torbay UA & 95 \\
13. & Thanet & 90 \\
14. & Ealing & 85 \\
15. & Wandsworth & 85 \\
16. & Bournemouth & 85 \\
17. Southend-on-Sea & 85 \\
18. & Croydon & 80 \\
19. Islington & 80 \\
20. & Tendring & 80 \\
\hline
\end{tabular}

The reforms to the Local Housing

Allowance (LHA) element of Housing Benefit impact most on the areas where the private rented sector accounts for a high proportion of households and where rent levels are highest.

Unsurprisingly, the biggest impact of this reform falls on London, and in particular on boroughs such as Westminster and Kensington and Chelsea where rents are exceptionally high.

A number of seaside towns are also hit hard. They too have large numbers in private rented housing. Some of this comprises former guest houses that have been subdivided into small flats and draw in lowincome and out-of-work households from surrounding areas and further afield.

Britain's older industrial areas, hit hard by many of the other welfare changes, are less acutely affected by the LHA reforms because a higher proportion of their low-income households live in the social rented sector (council and housing association) or in lowerprice owner-occupied property. 


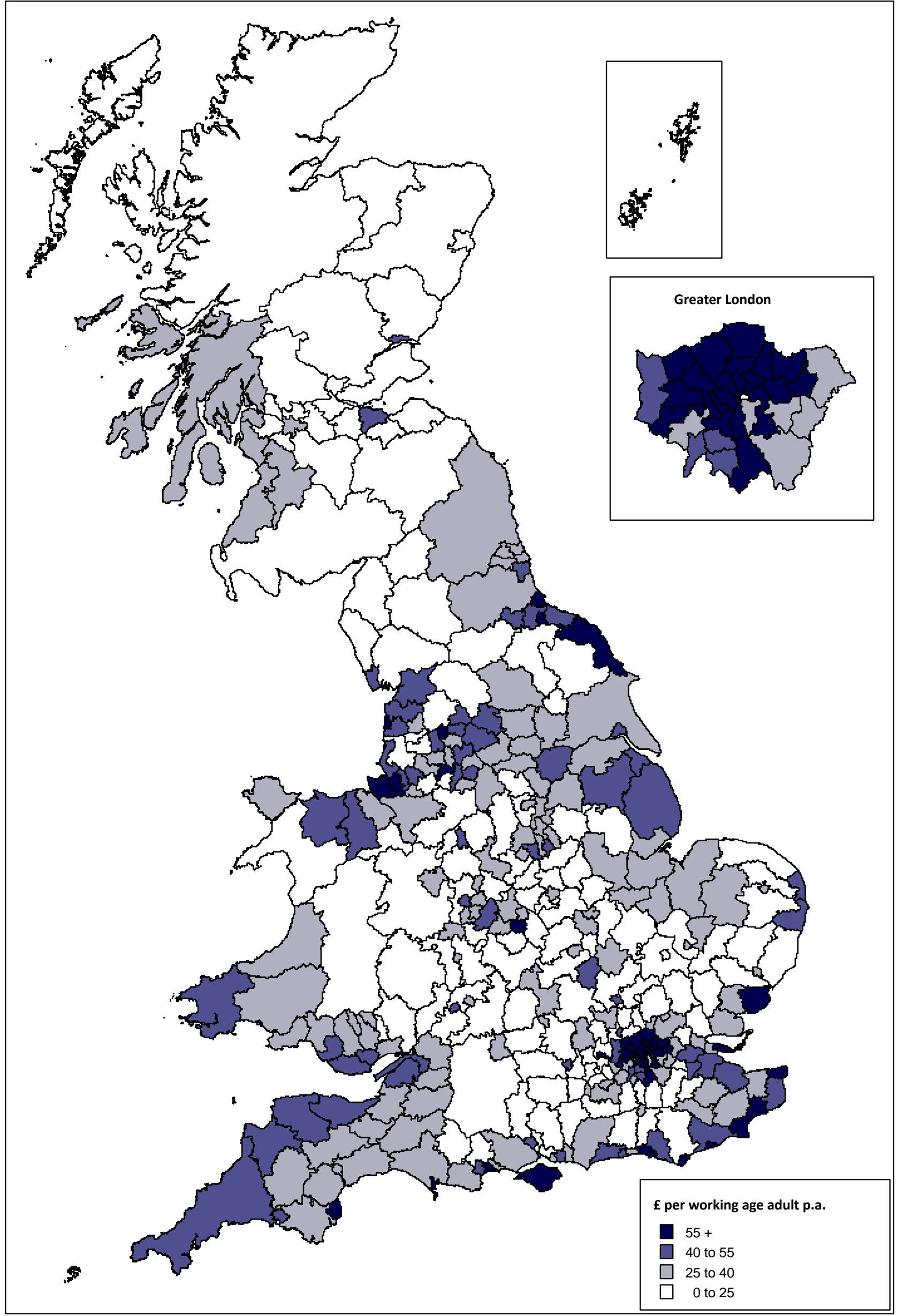

Source: Sheffield Hallam estimates based on official data 


\begin{tabular}{lcccc}
\hline & \multicolumn{4}{c}{ Housing Benefit: Under-occupation } \\
\cline { 2 - 5 } & $\begin{array}{c}\text { No of } \\
\text { h'holds affected }\end{array}$ & $\begin{array}{c}\text { Estimated } \\
\text { loss } \\
\text { Em p.a. }\end{array}$ & $\begin{array}{c}\text { No. of h'holds } \\
\text { affected } \\
\text { per 10,000 }\end{array}$ & $\begin{array}{c}\text { Financial loss per } \\
\text { working age adult } \\
\text { 乏 p.a. }\end{array}$ \\
\hline North East & 50,000 & 30 & 440 & 20 \\
North West & 110,000 & 80 & 370 & 18 \\
Yorkshire and the Humber & 80,000 & 50 & 360 & 16 \\
London & 80,000 & 90 & 240 & 15 \\
Scotland & 80,000 & 50 & 340 & 14 \\
Wales & 40,000 & 20 & 310 & 13 \\
West Midlands & 60,000 & 40 & 260 & 11 \\
East & 50,000 & 40 & 210 & 9 \\
East Midlands & 40,000 & 20 & 210 & 7 \\
South West & 30,000 & 20 & 130 & 6 \\
South East & 40,000 & 30 & 110 & $\mathbf{1 0}$ \\
\hline Great Britain & $\mathbf{6 6 0 , 0 0 0}$ & $\mathbf{4 9 0}$ & $\mathbf{2 6 0}$ & 9 \\
\hline
\end{tabular}

\begin{tabular}{rlc}
\hline WORST AFFECTED & $\begin{array}{c}\text { Loss per } \\
\text { working } \\
\text { age adult } \\
\text { 20 L.a. }\end{array}$ \\
\hline 1. & South Tyneside & 30 \\
2. & Knowsley & 29 \\
3. & Hackney & 28 \\
4. & Islington & 28 \\
5. & Manchester & 27 \\
6. & Salford & 27 \\
7. & Kingston upon Hull & 26 \\
8. & City of London & 26 \\
9. & Tower Hamlets & 26 \\
10. & Liverpool & 25 \\
11. & Southwark & 25 \\
12. & Gateshead & 24 \\
13. & Newcastle upon Tyne & 24 \\
14. & Glasgow & 24 \\
15. & West Dunbartonshire & 24 \\
16. & Hartlepool & 23 \\
17. & Middlesbrough & 23 \\
18. & Sunderland & 23 \\
19. & Halton & 23 \\
20. & St. Helens & 23 \\
\hline
\end{tabular}

The new rules affecting under-occupation of social housing (widely known as the 'bedroom tax') impact most in the places where a high proportion of the housing stock is rented from councils or housing associations. These areas include much of older industrial Britain and a number of London boroughs.

Outside London, there are four main areas where the financial loss is especially large.

One is the urban parts of North East England. The second is in North West England, including Manchester and Liverpool. The third is in West and South Yorkshire. The fourth is in the West of Scotland, in and around Glasgow. These places mostly have high worklessness as well as a high proportion in social housing.

Large parts of southern and eastern England are barely affected by this reform. They have relatively little social housing and relatively few people out-of-work on benefits. 


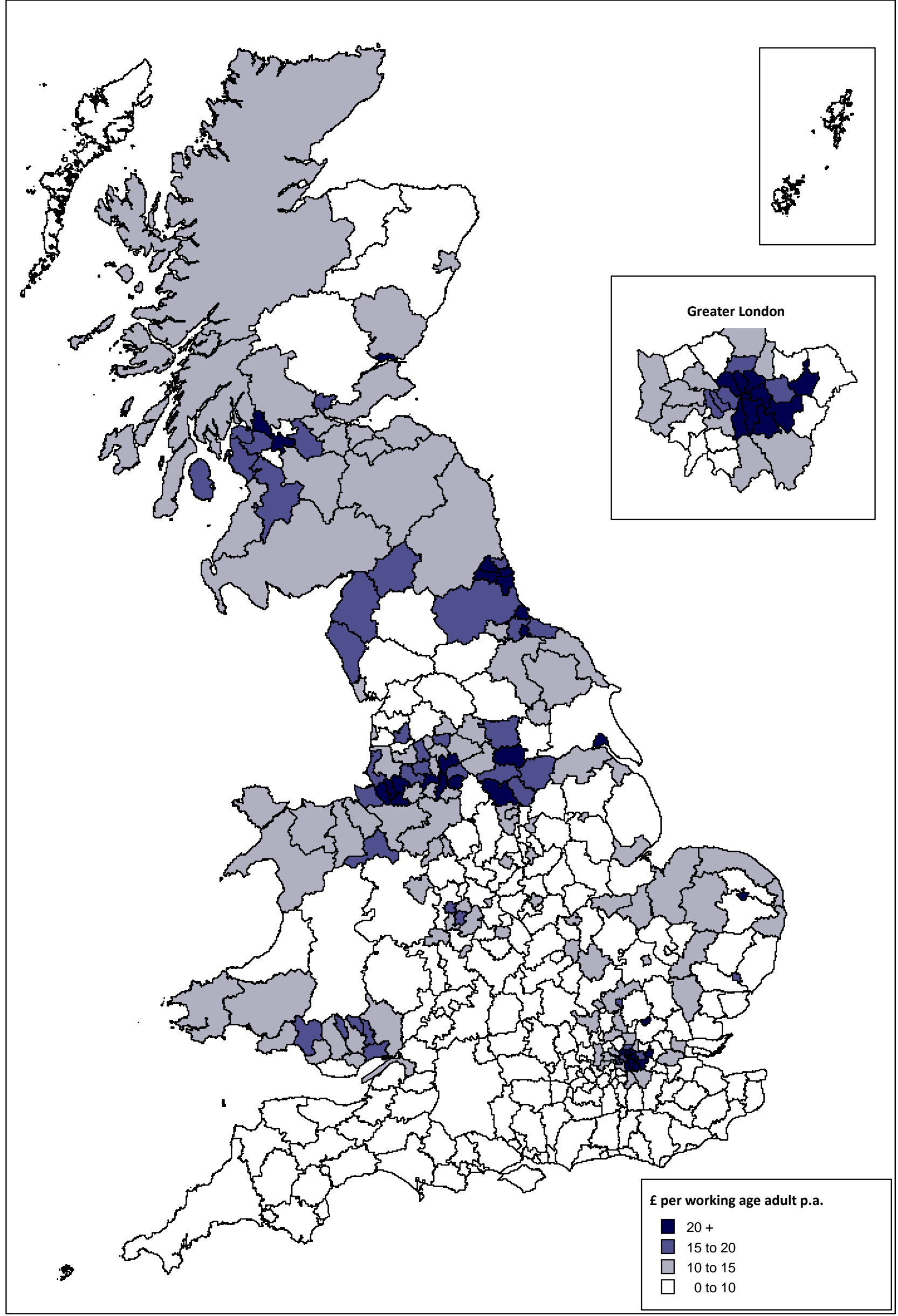

Source: Sheffield Hallam estimates based on official data 


\begin{tabular}{lcccc}
\hline & \multicolumn{4}{c}{ Non-dependant deductions } \\
\cline { 2 - 5 } & $\begin{array}{c}\text { No of } \\
\text { h'holds affected }\end{array}$ & $\begin{array}{c}\text { Estimated } \\
\text { loss } \\
\text { Em p.a. }\end{array}$ & $\begin{array}{c}\text { No. of h'holds } \\
\text { affected } \\
\text { per 10,000 }\end{array}$ & $\begin{array}{c}\text { Financial loss per } \\
\text { working age adult } \\
\text { ⿷ p.a. }\end{array}$ \\
\hline North East & 16,000 & 20 & 140 & 11 \\
North West & 39,000 & 40 & 130 & 10 \\
Yorkshire and the Humber & 27,000 & 30 & 120 & 9 \\
West Midlands & 29,000 & 30 & 130 & 9 \\
London & 45,000 & 50 & 140 & 9 \\
Wales & 16,000 & 20 & 120 & 9 \\
Scotland & 28,000 & 30 & 120 & 9 \\
East Midlands & 20,000 & 20 & 110 & 8 \\
South West & 23,000 & 30 & 100 & 7 \\
East & 24,000 & 30 & 100 & 7 \\
South East & 32,000 & 40 & 90 & $\mathbf{1 0}$ \\
\hline Great Britain & $\mathbf{3 0 0 , 0 0 0}$ & $\mathbf{3 4 0}$ & $\mathbf{1 2 0}$ & \\
\hline
\end{tabular}

\begin{tabular}{rlc}
\hline WORST AFFECTED & $\begin{array}{c}\text { Loss per } \\
\text { working } \\
\text { age adult } \\
\text { [ p.a. }\end{array}$ \\
\hline 1. LOCAL AUTHORITIES & Blackpool & 16 \\
2. & Knowsley & 15 \\
3. & Hartlepool & 14 \\
4. & South Tyneside & 14 \\
5. & Glasgow & 14 \\
6. & Middlesbrough & 13 \\
7. & Salford & 13 \\
8. & Liverpool & 13 \\
9. & Kingston upon Hull & 13 \\
10. & Tendring & 13 \\
11. & Great Yarmouth & 13 \\
12. & Hackney & 13 \\
13. & Hastings & 13 \\
14. & Thanet & 13 \\
15. & Torbay & 13 \\
16. & Blaenau Gwent & 13 \\
17. & Dundee City & 13 \\
18. & West Dunbartonshire & 13 \\
19. & Sunderland & 12 \\
20. & Burnley & 12 \\
\hline
\end{tabular}

The increase in non-dependent

deductions, which mainly affect Housing Benefit entitlements, impacts principally on the places with high numbers out-of-work on benefits.

The worst affected places include Britain's older industrial areas but also a number of seaside towns where there is not only unemployment but also a high proportion claiming Housing Benefit.

A number of the less affluent London boroughs are also hit relatively hard.

Large parts of southern and eastern England outside London are little affected by the increase in the deductions. A number of rural areas in the North of England and in Scotland also escape relatively lightly. 


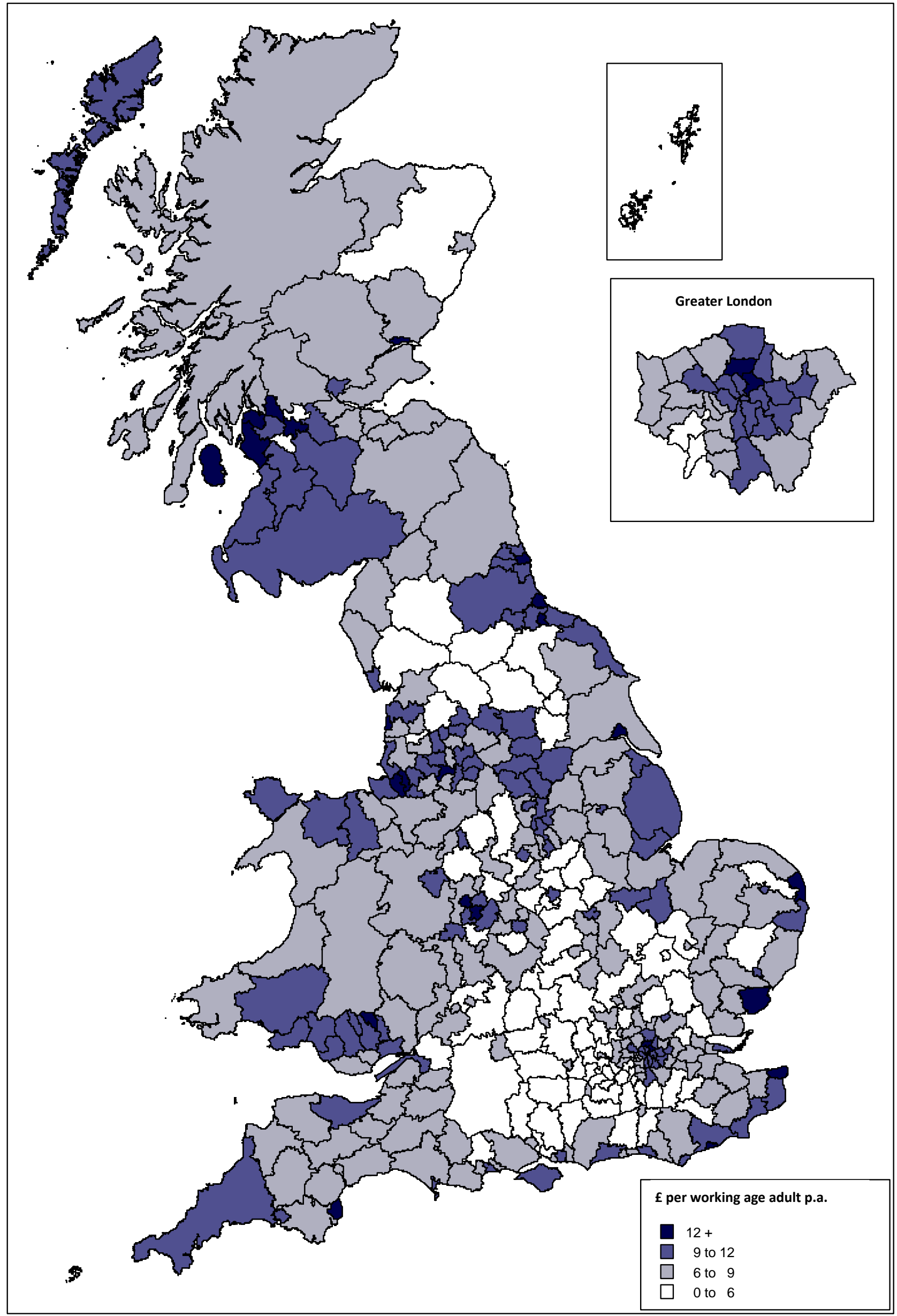

Source: Sheffield Hallam estimates based on official data 


\begin{tabular}{lcccc}
\hline & \multicolumn{4}{c}{ Household benefit cap } \\
\cline { 2 - 5 } & $\begin{array}{c}\text { No of } \\
\text { h'holds affected }\end{array}$ & $\begin{array}{c}\text { Estimated } \\
\text { loss } \\
\text { Em p.a. }\end{array}$ & $\begin{array}{c}\text { No. of h'holds } \\
\text { affected } \\
\text { per } \mathbf{1 0 , 0 0 0}\end{array}$ & $\begin{array}{c}\text { Financial loss per } \\
\text { working age adult } \\
\text { 乏 p.a. }\end{array}$ \\
\hline London & 26,600 & 130 & 80 & 23 \\
West Midlands & 3,800 & 20 & 20 & 5 \\
South East & 5,300 & 25 & 15 & 5 \\
North East & 1,500 & 5 & 15 & 4 \\
North West & 3,900 & 20 & 15 & 4 \\
Yorkshire and the Humber & 2,600 & 15 & 10 & 4 \\
East Midlands & 2,200 & 10 & 10 & 4 \\
East & 3,400 & 15 & 15 & 4 \\
South West & 2,500 & 10 & 10 & 4 \\
Wales & 1,700 & 10 & 15 & 4 \\
Scotland & 2,600 & 15 & 10 & $\mathbf{5}$ \\
\hline Great Britain & $\mathbf{5 6 , 0 0 0}$ & $\mathbf{2 7 0}$ & $\mathbf{2 0}$ & 4 \\
\hline
\end{tabular}

\begin{tabular}{rlc}
\hline WORST AFFECTED & $\begin{array}{c}\text { Loss per } \\
\text { working } \\
\text { age adult } \\
\text { 20 } \text {. } . \mathbf{a} .\end{array}$ \\
\hline 1. & Westminster & 64 \\
2. & Brent & 52 \\
3. & Enfield & 44 \\
4. & Kensington and Chelsea & 36 \\
5. & Tower Hamlets & 36 \\
6. & Barking and Dagenham & 32 \\
7. & Ealing & 32 \\
8. & Newham & 30 \\
9. & Hackney & 28 \\
10. & Haringey & 28 \\
11. & Hammersmith and Fulham & 24 \\
12. & Islington & 24 \\
13. & Camden & 23 \\
14. & Redbridge & 23 \\
15. & Barnet & 22 \\
16. & Waltham Forest & 20 \\
17. & Harrow & 19 \\
18. & Lewisham & 18 \\
19. & Wandsworth & 17 \\
20. & Croydon & 17 \\
\hline
\end{tabular}

The new household benefit cap impacts overwhelmingly on London. All the worst affected 20 local authorities are London boroughs.

London is hit hard because the benefit cap mostly comes into play for households that have hitherto been claiming large sums in Housing Benefit because of London's exceptionally high rent levels.

Unsurprisingly, Westminster, with the highest rent levels of all, faces the biggest impact.

But while the financial impact in some London borough is large, it is also worth bearing in mind that nationally, and even in London, the numbers of households affected are modest.

The household benefit cap barely impacts at all across large swathes of Britain away from London. 


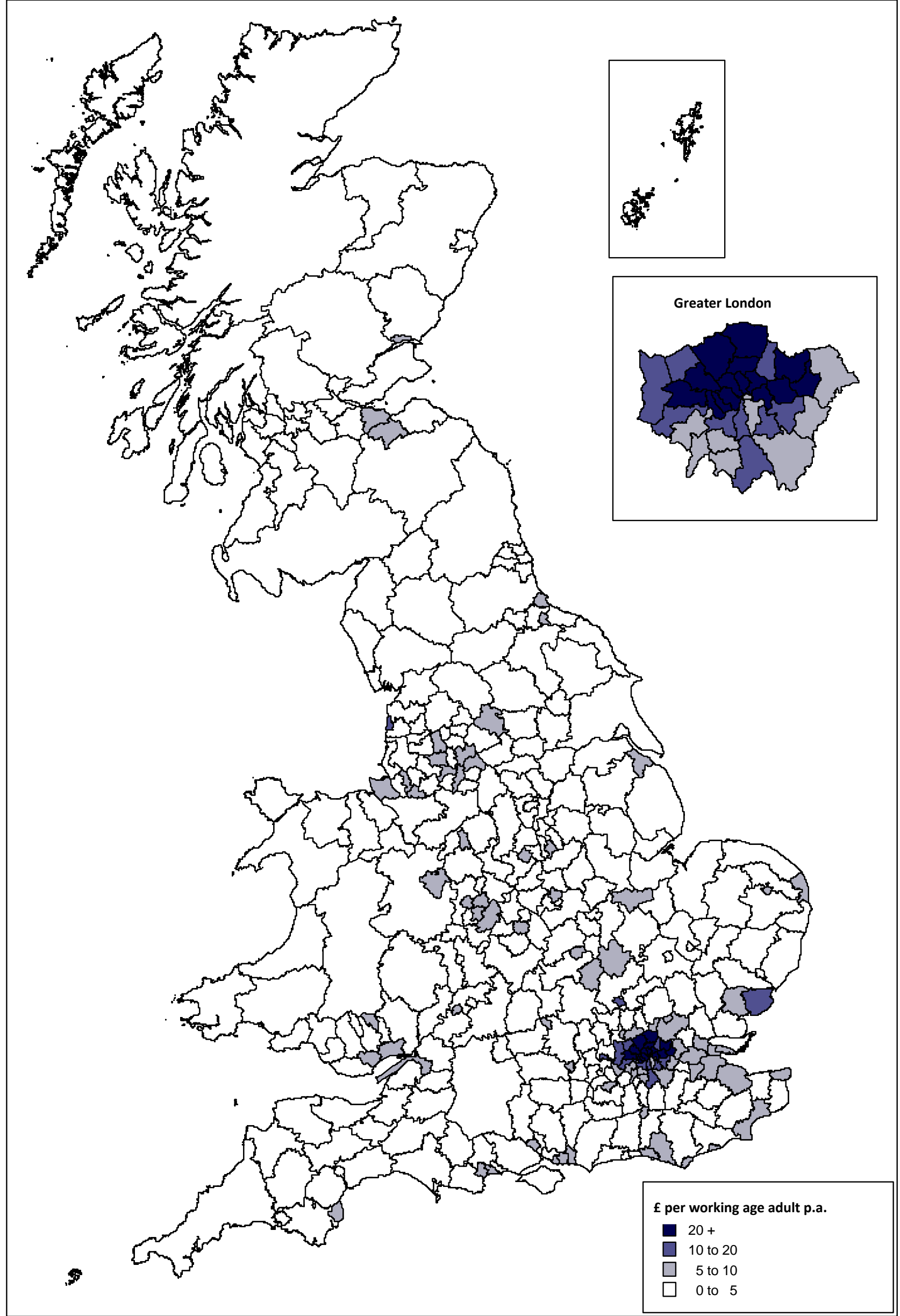

Source: Sheffield Hallam estimates based on official data 


\begin{tabular}{lcccc}
\hline & \multicolumn{4}{c}{ Council Tax Benefit } \\
\cline { 2 - 5 } & $\begin{array}{c}\text { No of } \\
\text { h'holds affected }\end{array}$ & $\begin{array}{c}\text { Estimated } \\
\text { loss } \\
\text { Em p.a. }\end{array}$ & $\begin{array}{c}\text { No. of h'holds } \\
\text { affected } \\
\text { per } \mathbf{1 0 , 0 0 0}\end{array}$ & $\begin{array}{c}\text { Financial loss per } \\
\text { working age adult } \\
\text { 乏 p.a. }\end{array}$ \\
\hline North West & 430,000 & 60 & 1,440 & 14 \\
Yorkshire and the Humber & 300,000 & 40 & 1,330 & 12 \\
London & 480,000 & 70 & 1,450 & 12 \\
North East & 140,000 & 20 & 1,190 & 10 \\
East & 220,000 & 40 & 900 & 10 \\
South West & 170,000 & 30 & 760 & 10 \\
West Midlands & 220,000 & 30 & 970 & 9 \\
East Midlands & 200,000 & 20 & 1,060 & 8 \\
South East & 280,000 & 30 & 800 & -0 \\
Wales & $0-$ & $0-$ & -0 & -0 \\
Scotland & -0 & -0 & -0 & $\mathbf{9}$ \\
\hline Great Britain & $\mathbf{2 , 4 5 0 , 0 0 0}$ & $\mathbf{3 4 0}$ & $\mathbf{9 5 0}$ & \\
\hline
\end{tabular}

\begin{tabular}{|c|c|c|}
\hline $\begin{array}{l}\text { WORST AFFECTED } \\
20 \text { LOCAL AUTHORITIES }\end{array}$ & $\begin{array}{l}\text { Loss per } \\
\text { working } \\
\text { age adult } \\
£ \text { p.a. }\end{array}$ & $\begin{array}{l}\text { The Westminster government has imposed a } \\
10 \text { per cent cut in Council Tax Benefit } \\
\text { payments to all parts of the country. }\end{array}$ \\
\hline 1. Blackpool & 40 & depends on whether it is passed on. \\
\hline 2. South Tyneside & 32 & In Scotland and Wales the devolved \\
\hline 3. Haringey & 31 & administrations have chosen not to pass on \\
\hline 4. Oldham & 30 & the cut to local authorities - so no impact on \\
\hline 5. Rochdale & 30 & claimants there. \\
\hline 6. Stoke-on-Trent & 30 & Some local authorities in England have \\
\hline 7. Torbay & 30 & chosen not to pass on the reduction, in whole \\
\hline 8. Middlesbrough & 28 & or in part, absorbing the loss by cuts \\
\hline 9. Brent & 28 & elsewhere in their budget. \\
\hline 10. Enfield & 28 & So the map partly reflects political choice. \\
\hline 11. Harlow & 27 & But it also reflects the government's \\
\hline 12. Knowsley & 26 & insistence that none of the reduction is \\
\hline 13. Redcar and Cleveland & 22 & passed on to pensioner households, so the \\
\hline 14. Liverpool & 22 & $\begin{array}{l}\text { full burden of the adjustment has to fall on } \\
\text { working age households. }\end{array}$ \\
\hline 15. Wirral & 22 & \\
\hline 16. Kirklees & 22 & In the parts of Britain where the reductions \\
\hline 17. Peterborough & 22 & have been passed on, and where there are \\
\hline 18. Southend-on-Sea & 22 & $\begin{array}{l}\text { large numbers of working-age claimants, the } \\
\text { impact is areatest }\end{array}$ \\
\hline 19. Hackney & 22 & \\
\hline 20. Harrow & 22 & \\
\hline
\end{tabular}

Sources: Sheffield Hallam estimates based on New Policy Institute data 


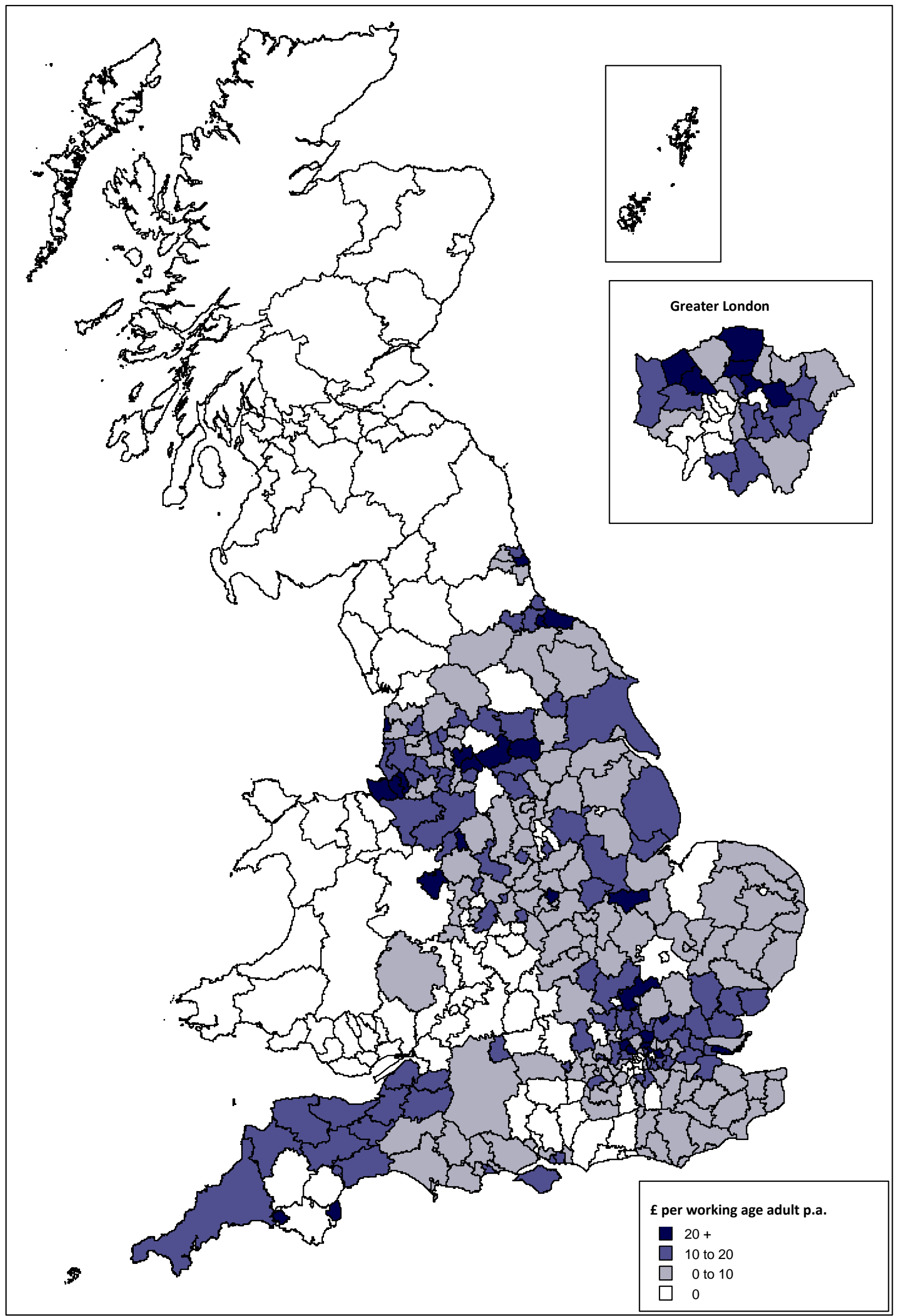

Source: Sheffield Hallam estimates based on New Policy Institute data 


\begin{tabular}{lcccc}
\hline & \multicolumn{4}{c}{ Disability Living Allowance } \\
\cline { 2 - 5 } & $\begin{array}{c}\text { No of } \\
\text { individuals } \\
\text { affected }\end{array}$ & $\begin{array}{c}\text { Estimated } \\
\text { loss } \\
\text { Em p.a. }\end{array}$ & $\begin{array}{c}\text { No. of individuals } \\
\text { affected } \\
\text { per } \mathbf{1 0 , 0 0 0}\end{array}$ & $\begin{array}{c}\text { Financial loss per } \\
\text { working age adult } \\
\text { 乏 p.a. }\end{array}$ \\
\hline Wales & 35,000 & 100 & 180 & 55 \\
Scotland & 55,000 & 170 & 160 & 50 \\
North East & 27,000 & 80 & 160 & 45 \\
North West & 72,000 & 220 & 160 & 45 \\
Yorkshire and the Humber & 45,000 & 140 & 130 & 40 \\
West Midlands & 47,000 & 140 & 130 & 40 \\
East Midlands & 37,000 & 110 & 120 & 35 \\
South West & 40,000 & 120 & 120 & 35 \\
East & 37,000 & 110 & 100 & 30 \\
London & 55,000 & 160 & 100 & 30 \\
South East & 53,000 & 160 & 100 & 30 \\
\hline Great Britain & $\mathbf{5 0 0 , 0 0 0}$ & $\mathbf{1 , 5 0 0}$ & $\mathbf{1 3 0}$ & $\mathbf{4 0}$ \\
\hline
\end{tabular}

\begin{tabular}{rlc}
\hline WORST AFFECTED & $\begin{array}{c}\text { Loss per } \\
\text { working } \\
\text { age adult } \\
\text { E p.a. }\end{array}$ \\
\hline 1. & Neath Port Talbot & 80 \\
2. & Merthyr Tydfil & 76 \\
3. & Knowsley & 74 \\
4. & Blackpool & 69 \\
5. & Blaenau Gwent & 69 \\
6. & West Dunbartonshire & 68 \\
7. & Caerphilly & 67 \\
8. & Glasgow & 67 \\
9. & Rhondda Cynon Taf & 65 \\
10. & Barrow-in-Furness & 63 \\
11. & Bridgend & 63 \\
12. & Inverclyde & 63 \\
13. & Liverpool & 62 \\
14. & Torfaen & 62 \\
15. & Bolsover & 61 \\
16. & East Lindsey & 61 \\
17. & Torbay UA & 61 \\
18. & Denbighshire & 60 \\
19. & Barnsley & 59 \\
20. & Dundee & 59 \\
\hline
\end{tabular}

The replacement of Disability Living Allowance (DLA) by Personal Independence Payments (PIP) impacts most on the places where the number of claimants is greatest.

The DLA claimant rate varies greatly across Britain, generally in line with the incapacity benefit claimant rate because most DLA claimants of working age are out-of-work on incapacity benefits.

The big numbers are in Britain's older industrial areas, where sickness and disability benefits have provided long-term support for men and women with problems in finding and retaining employment in difficult labour markets.

The South Wales Valleys, along with a number of older industrial areas in the North and Scotland and a number of seaside towns, lose most from the DLA reforms.

The financial loss in much of southern England, including most of London, is often only a quarter or a third that in the worst hit areas. 


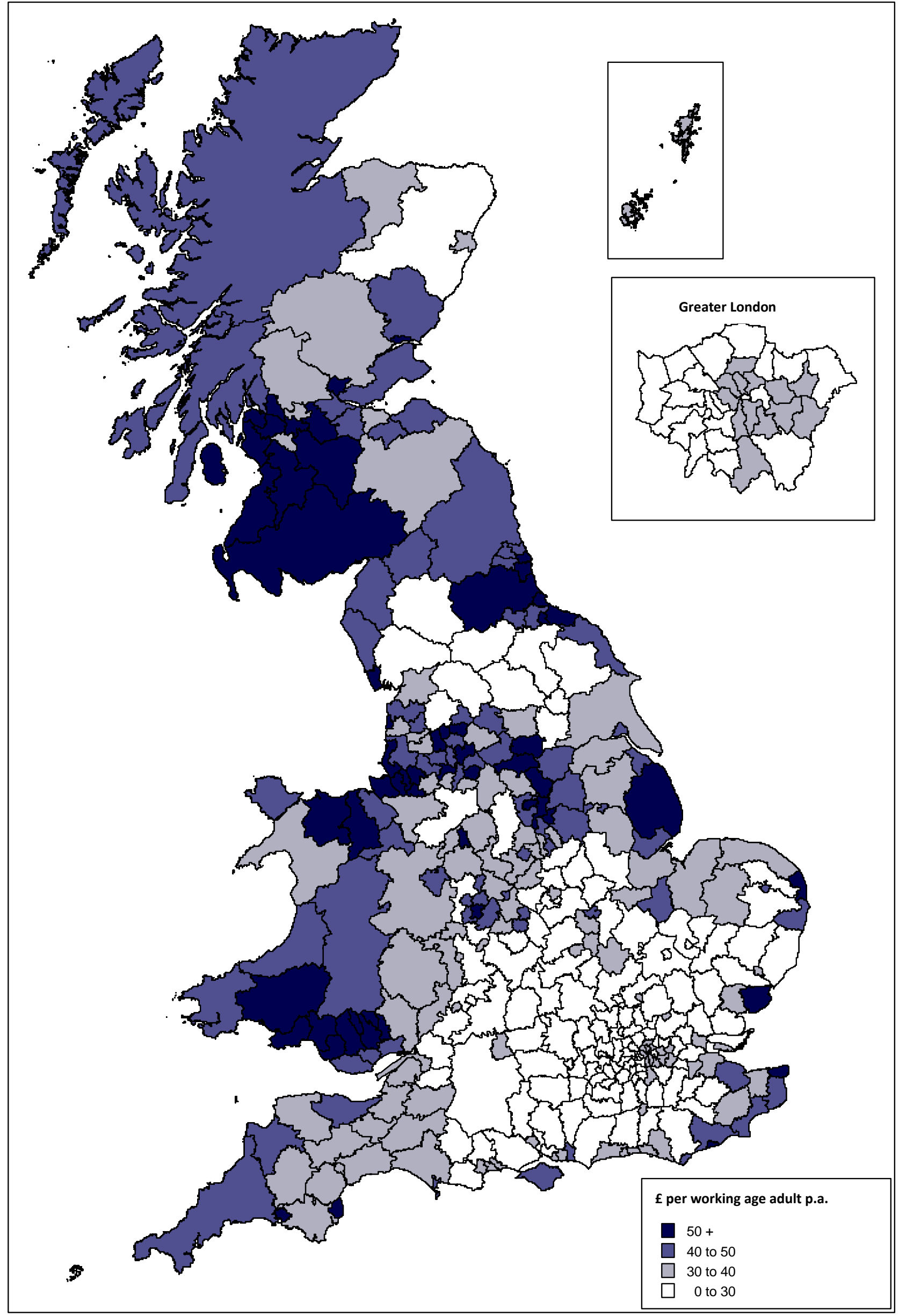

Source: Sheffield Hallam estimates based on official data 


\begin{tabular}{lcccc}
\hline & \multicolumn{4}{c}{ Incapacity benefits } \\
\cline { 2 - 5 } & $\begin{array}{c}\text { No of } \\
\text { individuals } \\
\text { affected }\end{array}$ & $\begin{array}{c}\text { Estimated } \\
\text { loss } \\
\text { Em p.a. }\end{array}$ & $\begin{array}{c}\text { No. of individuals } \\
\text { affected } \\
\text { per } \mathbf{1 0 , 0 0 0}\end{array}$ & $\begin{array}{c}\text { Financial loss per } \\
\text { working age adult } \\
\text { 乏 p.a. }\end{array}$ \\
\hline Wales & 93,000 & 320 & 480 & 165 \\
North East & 74,000 & 260 & 440 & 155 \\
North West & 197,000 & 690 & 430 & 150 \\
Scotland & 144,000 & 500 & 410 & 145 \\
Yorkshire and the Humber & 112,000 & 390 & 330 & 115 \\
West Midlands & 115,000 & 400 & 320 & 115 \\
East Midlands & 88,000 & 310 & 300 & 105 \\
South West & 92,000 & 320 & 280 & 100 \\
London & 147,000 & 470 & 260 & 85 \\
East & 83,000 & 300 & 220 & 80 \\
South East & 108,000 & 390 & 200 & 70 \\
\hline Great Britain & $\mathbf{1 , 2 5 0 , 0 0 0}$ & $\mathbf{4 , 3 5 0}$ & $\mathbf{3 1 0}$ & $\mathbf{1 1 0}$ \\
\hline
\end{tabular}

\begin{tabular}{clc}
\hline WORST AFFECTED & $\begin{array}{c}\text { Loss per } \\
\text { working } \\
\text { age adult } \\
\text { 20 L.a. }\end{array}$ \\
\hline 1. & Merthyr Tydfil & 265 \\
2. & Neath Port Talbot & 255 \\
3. & Blaenau Gwent & 255 \\
4. & Knowsley & 240 \\
5. & Rhondda Cynon Taf & 230 \\
6. & Glasgow & 225 \\
7. & Caerphilly & 225 \\
8. & Inverclyde & 220 \\
9. & Blackpool & 215 \\
10. & Barrow-in-Furness & 210 \\
11. & Liverpool & 210 \\
12. & Hartlepool & 200 \\
13. & Burnley & 200 \\
14. & Stoke-on-Trent & 200 \\
15. & West Dunbartonshire & 200 \\
16. & Barnsley & 195 \\
17. & Carmarthenshire & 195 \\
18. & Bridgend & 195 \\
19. & St. Helens & 190 \\
20. & Mansfield & 190 \\
\hline
\end{tabular}

The incapacity benefit reforms have by far their biggest impact on Britain's older industrial areas, where so many incapacity claimants are concentrated.

The three hardest hit local authorities are in the Welsh Valleys, and seven of the top 20 in South Wales. The rest of the list (with the notable exception of Blackpool) is a roll-call of older industrial Britain.

Since the mid-1980s, incapacity benefits have hidden the true scale of worklessness in Britain's weaker local economies, as men and women with health problems or disabilities have found that they have been able to access incapacity benefits instead of unemployment benefits.

Across Britain as a whole, incapacity claimants are by some margin the largest group out-of-work on benefits, and the cuts to incapacity benefits - these days Employment and Support Allowance - are especially large.

Much of southern England escapes lightly from these major cuts. 


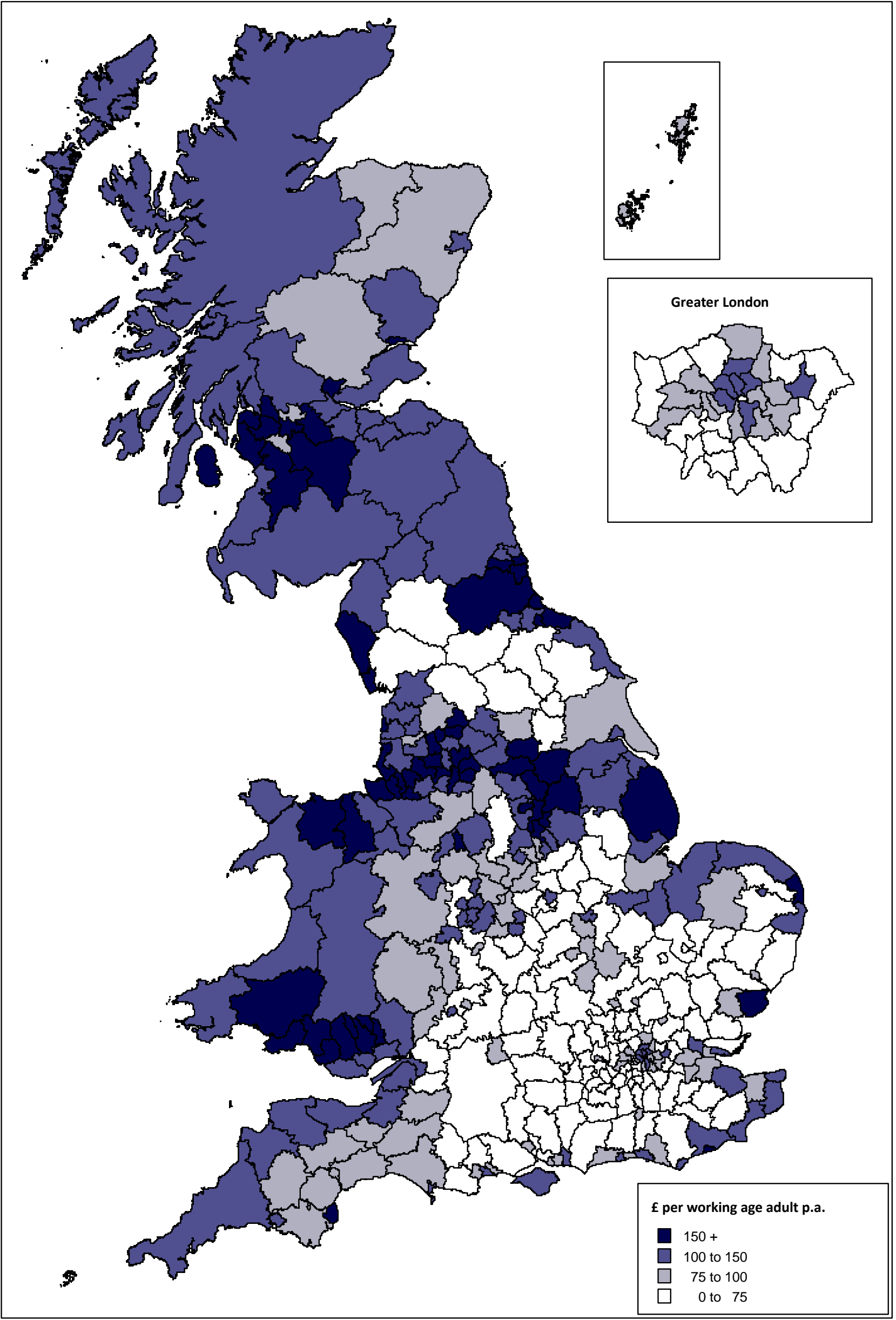

Source: Sheffield Hallam estimates based on official data 


\begin{tabular}{lcccc}
\hline & \multicolumn{4}{c}{ Child Benefit } \\
\cline { 2 - 5 } & $\begin{array}{c}\text { No of } \\
\text { h'holds affected }\end{array}$ & $\begin{array}{c}\text { Estimated } \\
\text { loss } \\
\text { Em p.a. }\end{array}$ & $\begin{array}{c}\text { No. of h'holds } \\
\text { affected } \\
\text { per 10,000 }\end{array}$ & $\begin{array}{c}\text { Financial loss per } \\
\text { working age adult } \\
\text { 乏 p.a. }\end{array}$ \\
\hline London & $1,040,000$ & 460 & 3,200 & 80 \\
South East & $1,060,000$ & 420 & 2,990 & 75 \\
East & 730,000 & 280 & 3,010 & 75 \\
West Midlands & 710,000 & 250 & 3,090 & 70 \\
North West & 900,000 & 320 & 2,980 & 70 \\
East Midlands & 560,000 & 200 & 2,960 & 70 \\
Yorkshire and the Humber & 660,000 & 230 & 2,960 & 70 \\
Wales & 370,000 & 130 & 2,860 & 65 \\
North East & 320,000 & 110 & 2,860 & 65 \\
South West & 620,000 & 220 & 2,750 & 65 \\
Scotland & 620,000 & 230 & 2,660 & 65 \\
\hline Great Britain & $\mathbf{7 , 6 0 0 , 0 0 0}$ & $\mathbf{2 , 8 5 0}$ & $\mathbf{2 , 9 6 0}$ & $\mathbf{7 0}$ \\
\hline
\end{tabular}

\begin{tabular}{rlr}
\hline WORST AFFECTED & $\begin{array}{c}\text { Loss per } \\
\text { working } \\
\text { age adult } \\
\text { 20 L.a. }\end{array}$ \\
\hline 1. & St Albans & 102 \\
2. & Barking and Dagenham & 99 \\
3. & Richmond upon Thames & 99 \\
4. & Elmbridge & 99 \\
5. & Hart & 98 \\
6. & Bromley & 96 \\
7. & Windsor and Maidenhead & 94 \\
8. & Bexley & 93 \\
9. & Wokingham & 93 \\
10. & Reigate and Banstead & 93 \\
11. & Broxbourne & 92 \\
12. & Surrey Heath & 92 \\
13. & Redbridge & 91 \\
14. & Enfield & 90 \\
15. & Hillingdon & 90 \\
16. & Chiltern & 90 \\
17. & Spelthorne & 90 \\
18. & North Hertfordshire & 89 \\
19. & Three Rivers & 89 \\
20. & Croydon & 89 \\
\hline Sources: & Sheffield Hallam estimates based on official data
\end{tabular}

The cuts to Child Benefit have a rather more even impact across Britain than most of the other welfare reforms - few places are more than a quarter above or below the national average.

This is partly because the three-year freeze in Child Benefit rates affects all claimants and most places have substantial numbers of children - and partly because the withdrawal of Child Benefit from households with a higher earner affects some household in most places.

The biggest impacts are in the places where there are substantial numbers of children and a high proportion of higher earners.

London's commuter belt, including a number of outer London boroughs, is hit hardest.

The cuts to Child Benefit are the only element of the welfare reforms that could be said to impact more on some of the most prosperous parts of Britain than on the poorest areas. 


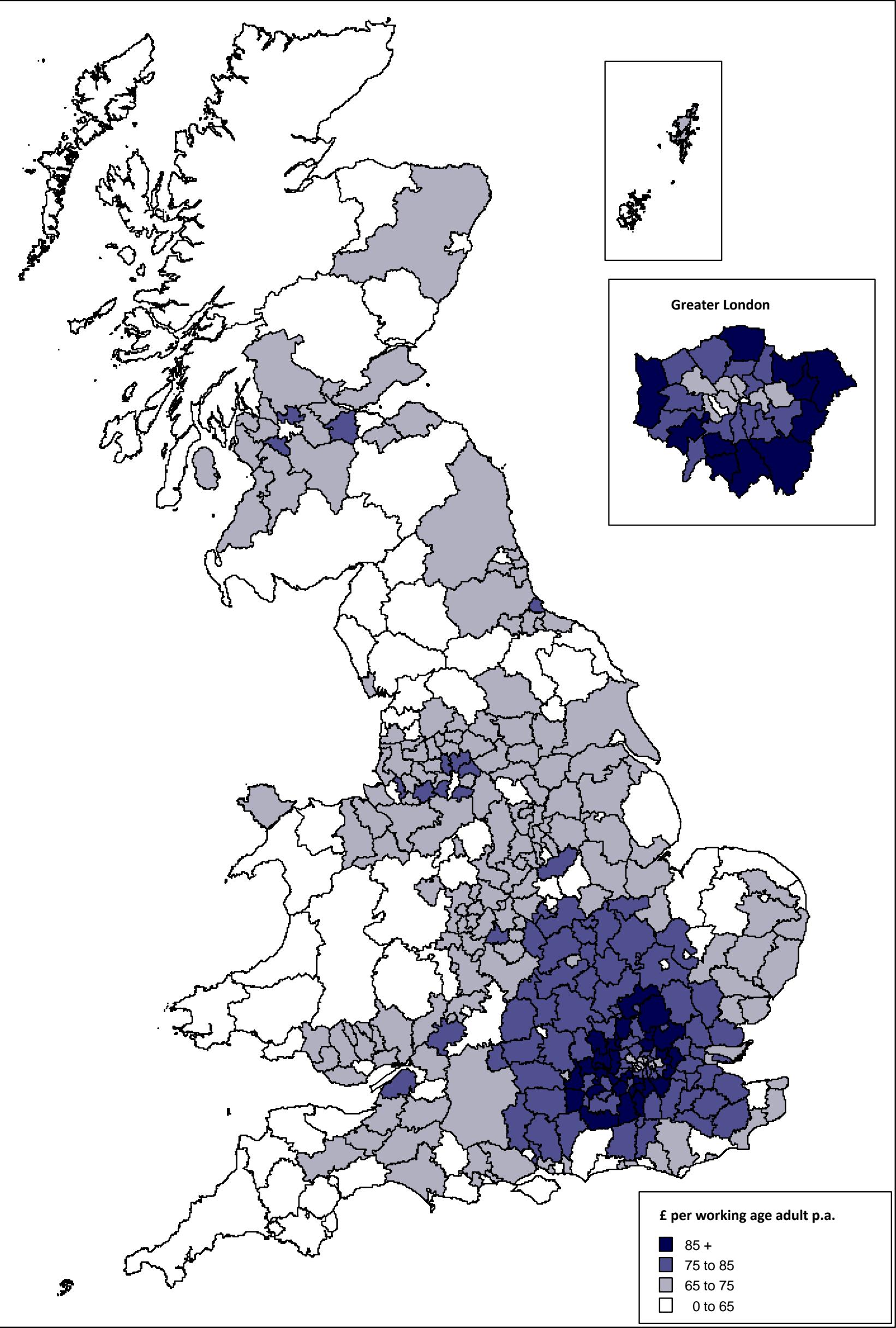

Source: Sheffield Hallam estimates based on official data 


\begin{tabular}{lcccc}
\hline & \multicolumn{4}{c}{ Tax Credits } \\
\cline { 2 - 5 } & $\begin{array}{c}\text { No of } \\
\text { h'holds affected }\end{array}$ & $\begin{array}{c}\text { Estimated } \\
\text { loss } \\
\text { Em p.a. }\end{array}$ & $\begin{array}{c}\text { No. of h'holds } \\
\text { affected } \\
\text { per 10,000 }\end{array}$ & $\begin{array}{c}\text { Financial loss per } \\
\text { working age adult } \\
\text { 乏 p.a. }\end{array}$ \\
\hline North East & 220,000 & 180 & 1,940 & 105 \\
North West & 600,000 & 480 & 1,980 & 105 \\
West Midlands & 460,000 & 370 & 2,000 & 105 \\
Yorkshire and the Humber & 440,000 & 350 & 1,960 & 105 \\
Wales & 250,000 & 200 & 1,900 & 105 \\
East Midlands & 350,000 & 280 & 1,820 & 95 \\
London & 610,000 & 500 & 1,870 & 90 \\
South West & 360,000 & 290 & 1,570 & 85 \\
Scotland & 370,000 & 300 & 1,600 & 85 \\
East & 370,000 & 300 & 1,540 & 80 \\
South East & 490,000 & 400 & 1,380 & $\mathbf{9 0}$ \\
\hline Great Britain & $\mathbf{4 , 5 0 0 , 0 0 0}$ & $\mathbf{3 , 6 6 0}$ & $\mathbf{1 , 7 5 0}$ & \\
\hline
\end{tabular}

\begin{tabular}{rlc}
\hline WORST AFFECTED & $\begin{array}{l}\text { Loss per } \\
\text { working } \\
\text { age adult } \\
\text { 20 LOC.a. }\end{array}$ \\
\hline 1. & Barking and Dagenham & 150 \\
2. & Blackpool & 146 \\
3. & Blackburn with Darwen & 144 \\
4. & Sandwell & 141 \\
5. & Knowsley & 140 \\
6. & Burnley & 138 \\
7. & Kingston upon Hull & 136 \\
8. & Bradford & 136 \\
9. & Boston & 136 \\
10. & Peterborough & 136 \\
11. & Oldham & 135 \\
12. & Thanet & 135 \\
13. & Hyndburn & 133 \\
14. & Corby & 133 \\
15. & Birmingham & 133 \\
16. & Leicester & 132 \\
17. & Middlesbrough & 131 \\
18. & Rochdale & 130 \\
19. & Pendle & 130 \\
20. & Newham & 129 \\
\hline Sources: & Sheffield Hallam estimates based on official data
\end{tabular}

Tax Credits - Child Tax Credit and Working Families Tax Credit - are paid to lower and middle-income families, so the impact of reductions in eligibility and payment rates is felt most in the places where less well-off people live.

The list of local authorities most affected comprises a combination of urban and rural areas with relatively low wages and high unemployment.

London's commuter belt and a number of more prosperous rural areas are affected less by the cuts to Tax Credits.

At the regional scale, the North of England loses more than the South, but overall the differences across Britain are less pronounced than for some of the other welfare reforms. 


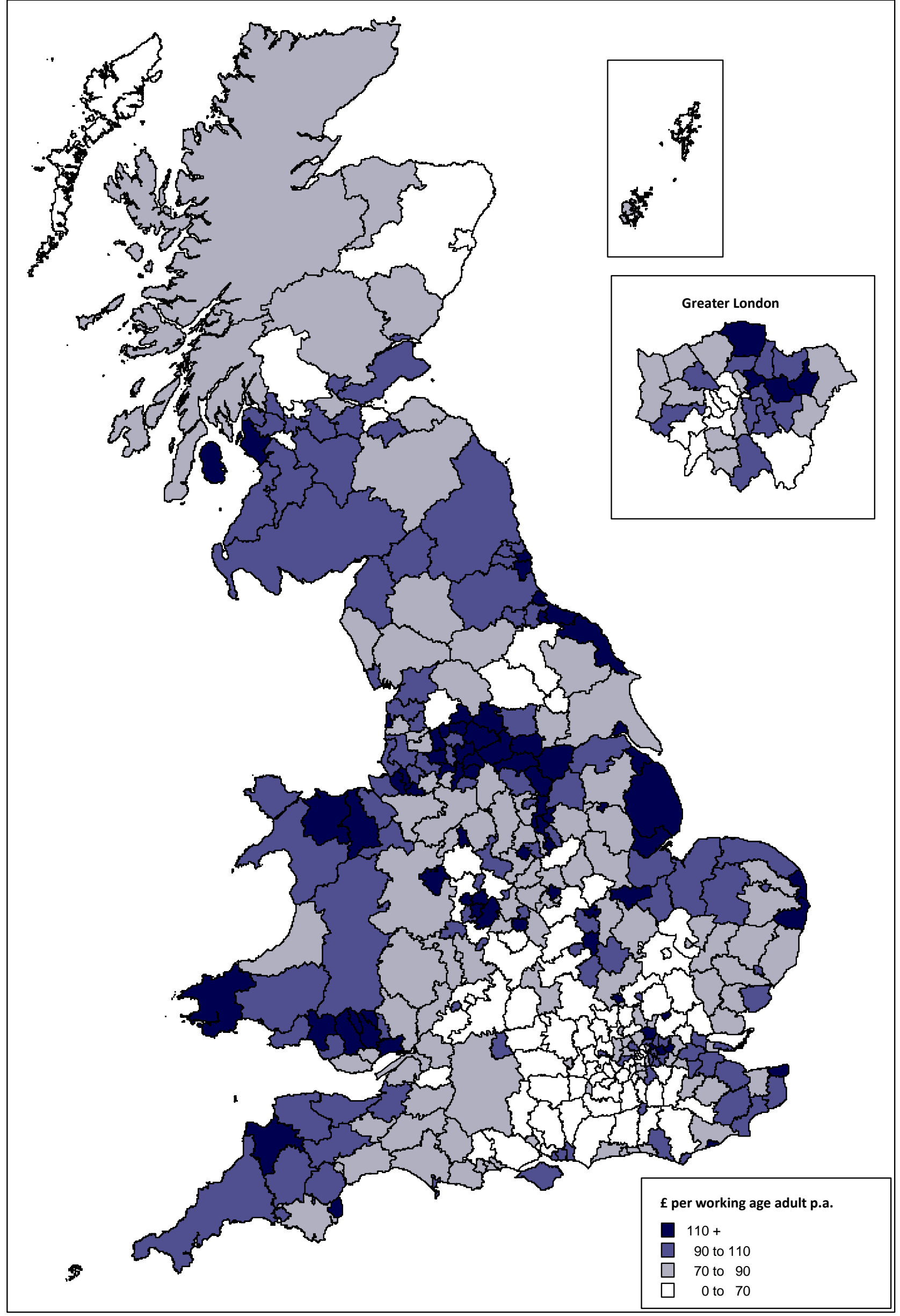

Source: Sheffield Hallam estimates based on official data 
1 per cent uprating

\begin{tabular}{cccc}
\hline $\begin{array}{c}\text { No of } \\
\text { h'holds affected }\end{array}$ & $\begin{array}{c}\text { Estimated } \\
\text { loss } \\
\text { \&m p.a. }\end{array}$ & $\begin{array}{c}\text { No. of h'holds } \\
\text { affected } \\
\text { per } \mathbf{1 0 , 0 0 0}\end{array}$ & $\begin{array}{c}\text { Financial loss per } \\
\text { working age adult } \\
\text { \& p.a. }\end{array}$ \\
\hline n.a. & 170 & n.a. & 100 \\
n.a. & 460 & n.a. & 100 \\
n.a. & 190 & n.a. & 100 \\
n.a. & 320 & n.a. & 95 \\
n.a. & 330 & n.a. & 95 \\
n.a. & 520 & n.a. & 95 \\
n.a. & 290 & n.a. & 85 \\
n.a. & 240 & n.a. & 85 \\
n.a. & 260 & n.a. & 80 \\
n.a. & 270 & n.a. & 75 \\
n.a. & 370 & n.a. & 65 \\
\hline & & n.a. & $\mathbf{9 0}$ \\
n.a. & $\mathbf{3 , 4 3 0}$ & &
\end{tabular}

\begin{tabular}{rlc}
\hline WORST AFFECTED & $\begin{array}{c}\text { Loss per } \\
\text { working } \\
\text { age adult } \\
\text { 20 L.a. }\end{array}$ \\
\hline 1. & Blackpool & 169 \\
2. & Knowsley & 139 \\
3. & Barking and Dagenham & 138 \\
4. & Thanet & 138 \\
5. & Enfield & 137 \\
6. & Hastings & 137 \\
7. & Middlesbrough & 134 \\
8. & Torbay & 133 \\
9. & Burnley & 132 \\
10. & Hartlepool & 129 \\
11. & Kingston upon Hull & 129 \\
12. & Blackburn with Darwen & 126 \\
13. & Liverpool & 124 \\
14. & Merthyr Tydfil & 124 \\
15. & Blaenau Gwent & 124 \\
16. & Hyndburn & 123 \\
17. & Birmingham & 123 \\
18. & Sandwell & 123 \\
19. & Newham & 123 \\
20. & Great Yarmouth & 121 \\
\hline Sources: Sheffield Hallam estimates based on official data
\end{tabular}

The 1 per cent up-rating of a wide range of working-age benefits inevitably impacts most where these benefits are claimed by the largest number of people.

This means that places with high numbers out-of-work on benefits or with large numbers claiming Housing Benefit or in-work benefits are the ones hit hardest.

In practice, therefore, the 1 per cent up-rating reinforces the local and regional impact of a range of other welfare reforms.

Britain's older industrial areas, a number of seaside towns and some London boroughs face the greatest impacts.

Once more, it is large parts of southern and eastern England outside London that escape with the smallest financial losses. 


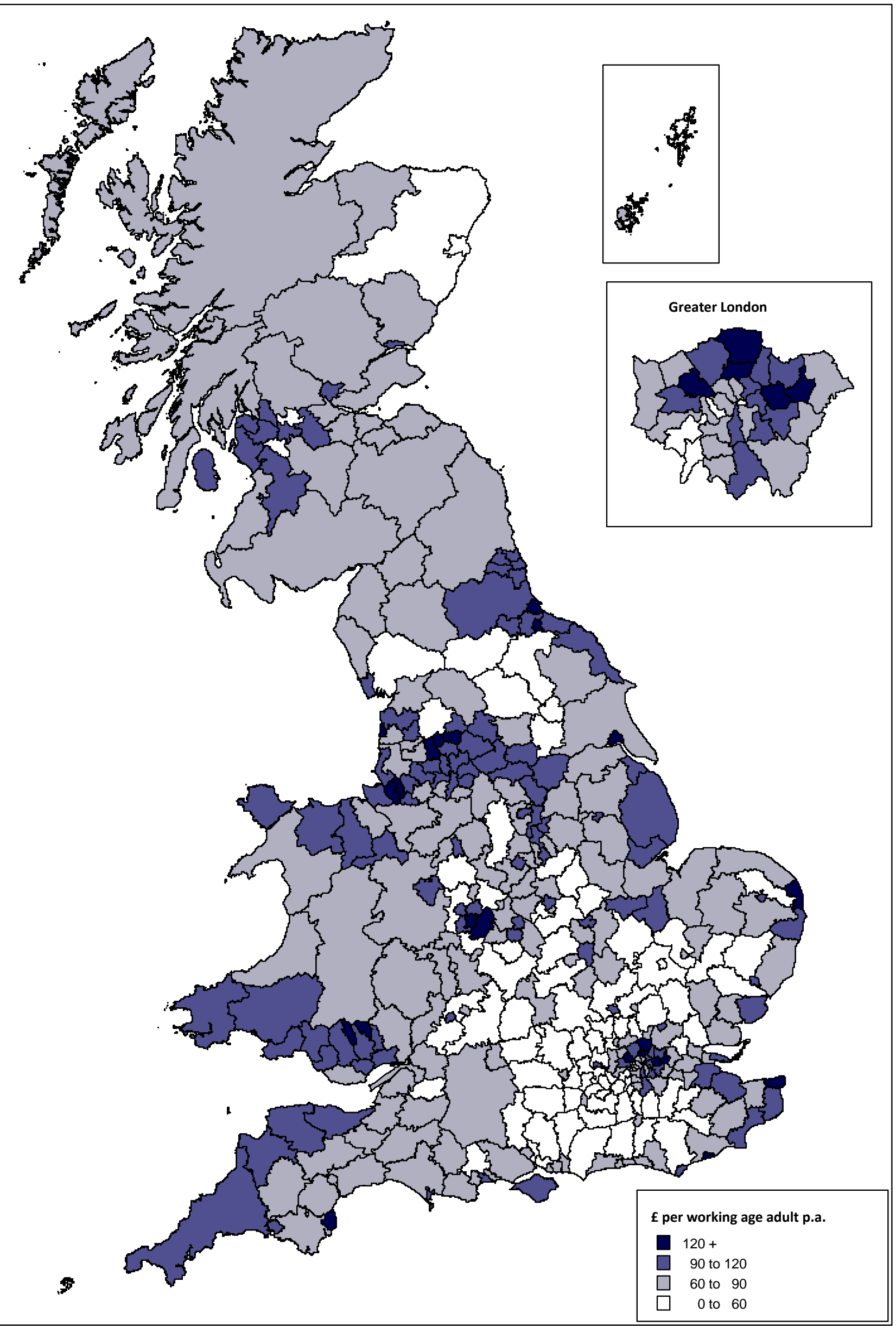

Source: Sheffield Hallam estimates based on official data 


\section{HOUSING BENEFIT: (1) LOCAL HOUSING ALLOWANCE}

Rules governing assistance with the cost of housing for low-income households in the private rented sector

\section{Nature of reforms}

- Maximum rents set at $30^{\text {th }}$ percentile of local rents, rather than $50^{\text {th }}$ percentile, from 2011-12

- Caps on maximum rents for each property size, with 4-bed limit, from 2011-12

- Abolition of $£ 15$ excess formerly retained by tenants paying below maximum LHA rent, from 201112

- Increase age limit for shared room rate from 25 to 35, from January 2012

- Switch from $30^{\text {th }}$ percentile rents to CPI indexation for LHA, from 2013-14

\section{Total estimated loss}

$£ 1,645 \mathrm{~m}$ a year by $2014-15$

(Source: HM Treasury)

\section{Methods and data sources}

- Total loss arising from $30^{\text {th }}$ percentile, size caps and $£ 15$ excess $(£ 1040 \mathrm{~m}$ pa) allocated to local authorities on the basis of DWP estimates of the number of households affected and the average final loss (Source: DWP Impacts of Housing Benefit proposals: changes to LHA to be introduced in 2011-12)

- Loss arising from increase in age limit for shared room rate $(£ 215 \mathrm{~m}$ pa) allocated to local authorities on the basis of estimates of the numbers losing and average loss per week in each authority (Source: DWP Housing Benefit equality impact assessment: increasing the shared accommodation rate age threshold to 35)

- Loss arising from CPI indexation ( $£ 390 \mathrm{~m}$ pa) allocated to local authorities on the basis of the number of Housing Benefit claims in the private rented sector in each authority in August 2012 (Source: DWP)

- Number of affected households based on number of Housing Benefit claimants in August 2012 in the private rented sector in each authority and the national share receiving LHA (Source: DWP). NB All LHA recipients affected by shift to CPI indexation.

\section{HOUSING BENEFIT: (2) UNDER-OCCUPATION}

New rules governing the size of properties for which payments are made to working age claimants in the social rented sector (council and housing association)

\section{Nature of the reform}

- Limit Housing Benefit payments to working-age households in social rented accommodation to a level reflecting the number of bedrooms justified by the size and age composition of the household, from 2013-14 


\section{Total estimated loss}

$£ 490 \mathrm{~m}$ a year by $2014-15$

(Source: HM Treasury)

\section{Methods and data sources}

- Estimated number of households affected in each region (Source: DWP Impact Assessment Housing Benefit: under-occupation of social housing, June 2012 update) allocated by region to each local authority on the basis of the number in social housing claiming Housing Benefit in August 2012 (Source: DWP)

- Financial loss allocated to each local authority on the basis of estimated number of affected households (see above) and estimated average loss per claimant in each region (Source: DWP Impact Assessment, June 2012 update)

\section{NON-DEPENDANT DEDUCTIONS}

Deductions from Housing Benefit, Council Tax Benefit and other income-based benefits to reflect the contribution that non-dependant household members are expected to make towards the household's housing costs.

\section{Nature of reform}

- Up-rating the deductions in stages between April 2011 and April 2014 to reflect growth in rents and increases in Council Tax since 2001, when the deductions were frozen, and subsequent link to prices

\section{Total estimated loss}

$£ 340 \mathrm{~m}$ a year by $2014-15$

(Source: HM Treasury)

\section{Methods and data sources}

- Estimated 300,000 claimants affected (Source: DWP Equality Impact Assessment: incomerelated benefits: changes to the non-dependent deduction rates) allocated on the basis of the number of Housing Benefit and Council Tax Benefit claimants in each local authority in August 2012 (Source: DWP).

- Financial loss allocated to local authorities on the basis of the estimated numbers affected (see above)

\section{HOUSEHOLD BENEFIT CAP}

New ceiling on total payments per household applying to wide range of benefits, including Child Benefit, Child Tax Credit, Employment and Support Allowance, Housing Benefit, Incapacity Benefit, Income Support and Jobseeker's Allowance

\section{Nature of reforms}

- Total household benefit payments for working-age claimants capped so that workless households receive no more in benefit than the average weekly wage, after tax and national insurance, from 2013-14, administered through Housing Benefit payments 


\section{Total estimated loss}

$£ 270 \mathrm{~m}$ a year by $2014-15$

(Source: HM Treasury)

\section{Methods and data sources}

- Loss allocated to local authorities on the basis of the number of individuals in each authority in receipt of a letter notifying them that they may be affected by the benefit cap (Source: DWP)

- National total of 56,000 households expected to be capped in 2013/14 (Source: DWP Benefit Cap (Housing Benefit regulations 2012): impact assessment for the benefit cap) allocated to local authorities in proportion to letters of notification.

\section{COUNCIL TAX BENEFIT}

Paid to households on low incomes to offset Council Tax bills, in whole or in part

\section{Nature of the reform}

- 10 per cent reduction in expenditure by HM Treasury and transfer of responsibility for the scheme to local authorities, from 2013-14.

- Reduction in entitlement only permitted for working-age households; entitlement of pensioner households fully protected.

- Some local authorities in England have chosen not to pass on the reduction to claimants, in whole or in part, absorbing the cut within their budget. In Scotland and Wales the devolved administrations have made arrangements that avoid the reduction falling on claimants.

\section{Total estimated loss}

$£ 490 \mathrm{~m}$ a year by 2014-15 (Source: HM Treasury)

of which an estimated $£ 340 \mathrm{~m}$ a year is being passed on to claimants

\section{Methods and data sources}

- Number of households affected and average weekly loss, by authority, from statistics assembled by the New Policy Institute, as updated on $7^{\text {th }}$ February 2013 at www.npi.org.uk. The NPI calculations are based on information assembled from each local authority.

- The NPI data shows that some local authorities in England have chosen not to pass on the benefit reduction to claimants, in whole or in part, absorbing the cut elsewhere within their budget. In Scotland and Wales the devolved administrations have not passed on the cut to local authorities, thereby avoiding any impact on claimants.

- Where the NPI identifies only 'minor changes' the impact has been set to zero.

\section{DISABILITY LIVING ALLOWANCE}

Payments intended to help offset the additional financial costs faced by individuals of all ages with disabilities, including those both in and out of work

\section{Nature of reform}

- Phased replacement of Disability Living Allowance (DLA) for working-age claimants by Personal Independence Payments (PIP), from 2013-14 
- Introduction of more stringent medical test and regular re-testing

- Reduction in number of payment categories

\section{Total estimated loss}

$£ 1,500 \mathrm{~m}$ a year by $2017-18$

(Source: DWP Impact Assessment Disability Living Allowance reform, adjusted for inflation and revised implementation timetable)

\section{Methods and data sources}

- Anticipated reduction in national caseload of working age to $1.7 \mathrm{~m}$ (Source: DWP Impact Assessment) represents a 23 per cent reduction in anticipated numbers in absence of reform

- Numbers affected refer to the 23 per cent reduction in claimants, allocated on the basis of stock of working age DLA claimants in each local authority in February 2012 (Source: DWP). Additionally, a number of claimants in receipt of PIP instead of DLA may experience a reduction in payment.

- Financial loss allocated to each local authority on basis of reduction in claimant numbers (see above)

\section{INCAPACITY BENEFITS}

Out-of-work payments to men and women of working age with health problems or disabilities, including Employment and Support Allowance (ESA) and its predecessors Incapacity Benefit, Income Support on grounds of disability, and Severe Disablement Allowance

\section{Nature of reforms}

- Introduction of ESA for new claimants and a new, tougher medical test (the Work Capability Assessment), from October 2008

- Applying the Work Capability Assessment to existing incapacity claimants from autumn 2010 onwards, and migration to ESA if not deemed 'fit for work'

- Time-limiting to 12 months non-means tested entitlement for ESA Work Related Activity Group, from 2012-13

- New conditionality for ESA Work Related Activity Group

\section{Total estimated loss}

$£ 4,350 \mathrm{~m}$ a year by $2015-16$, comprising:

- $£ 2,600 \mathrm{~m}$ a year from time limiting of non-means tested entitlement (Source: HM Treasury estimates for 2014-15, revised to take account of inflation and additional numbers affected by 2015-16)

- c. $£ 1,750 \mathrm{~m}$ a year from remaining measures (see below)

\section{Methods and data sources}

- By 2015-16, an estimated 700,000 will be affected by time limiting non-means tested ESA entitlement. Of these, 40 per cent are anticipated to lose benefit entirely and the remaining 60 per cent will experience a reduction in payment (Source: DWP Impact Assessment Time limit contributory Employment and Support Allowance to one year for those in the Work-Related Activity Group).

- By 2014 an additional 550,000 are estimated to be denied ESA by other elements of the reforms, of which 30 per cent will not claim alternative benefits (Source: Beatty and Fothergill 2011, 
Incapacity benefit reform: the local regional and national impact, CRESR, Sheffield Hallam University).

- Numbers affected by local authority allocated on the basis of methods in Beatty and Fothergill (2011) based primarily on DWP claimant data, DWP impact assessments and DWP evidence from pilot areas.

- Financial loss arising from time limiting allocated in 3:1 ratio between those losing benefit entirely and those retaining benefit at reduced rate, on the basis of estimated numbers in each group by local authority.

- Financial loss arising from other elements of the reforms estimated to be two-thirds that arising from time limiting, given of numbers affected and proportion expected to be denied benefits. (Treasury or DWP estimates have not been published). Loss allocated in 2:1 ratio between those denied benefit entirely and those claiming other benefits at a lower rate, on the basis of estimated numbers in each group by local authority.

\section{CHILD BENEFIT}

Paid to households on the basis of the number of children up to age 16 or, if they remain at school or in further education, up to 19

\section{Nature of reforms}

- Freeze benefit rates for three years from 2011-12, instead of up-rate with inflation

- Withdrawal of benefit from households including a higher earner (threshold at $£ 50,000$ and taper to $£ 60,000$ ), from January 2013

\section{Total estimated loss}

$£ 2,845 \mathrm{~m}$ a year by $2014-15$

(Source: HM Treasury)

\section{Methods and data sources}

- Numbers of families in receipt of Child Benefit, by local authority in August 2011, from HMRC (Source: HMRC Child Benefit Statistics: geographical analysis). NB All recipients affected by freeze.

- Financial loss arising from freeze $(£ 975 \mathrm{~m}$ pa) allocated on basis of number of families in receipt of Child Benefit in each local authority (see above)

- Financial loss arising from withdrawal of benefit from high earners $(£ 1,870 \mathrm{~m}$ pa) allocated on basis of number of families in receipt of Child Benefit multiplied by an index of median earnings in the three years 2010, 2011 and 2012 of residents in each local authority relative to the UK average (Source: Annual Survey of Hours and Earnings). County averages used where earnings data for districts is unavailable.

\section{TAX CREDITS}

Payments through the tax system of Child Tax Credit (CTC) and Working Families Tax Credit (WFTC) to lower and middle income households

\section{Nature of reforms}

- Adjustments to thresholds, withdrawal rates, supplements, income disregards and backdating provisions, from 2011-12 onwards 
- Changes in indexation and up-rating, from 2011-12 onwards

- Reductions in childcare element of WFTC, from 2011-12

- Increase in working hours requirement for WFTC, from 2012-13

Total estimated loss

$£ 3,660 \mathrm{~m}$ (net) a year by $2014-15$

(Source: HM Treasury)

\section{Methods and data sources}

- Overall loss allocated on the basis of the total number of families in receipt of CTC or WFTC in December 2012, by local authority (Source: HMRC Child and Working Tax Credits Statistics: geographical analysis)

- All families in receipt of CTC or WFTC affected by one or more of the changes

\section{PER CENT UP-RATING}

Annual up-rating of value of benefits

\section{Nature of reform}

- 1 per cent up-rating (instead of by CPI) for three years from 2013-14 for main working-age benefits, and for two years from 2014-15 for Child Benefit and for Local Housing Allowance within Housing Benefit

\section{Total estimated loss}

$£ 3,430 \mathrm{~m}$ a year by $2015-16$

(Source: HM Treasury)

\section{Methods and data sources}

- Total loss divided equally between DWP-administrated benefits and HMRC-administrated benefits (Child Benefit, CTC, WFTC), reflecting split of overall expenditure on relevant benefits (Sources: DWP and HMRC)

- HMRC benefits loss allocated on basis of total number of families in receipt of CTC or WFTC in December 2012, (Source: HMRC Child and Working Tax Credits: geographical analysis)

- DWP benefits loss divided 75:25 between working age benefits and Housing Benefit, reflecting split of overall expenditure on relevant benefits (Source: DWP)

- DWP working age benefits loss allocated on basis of non-employed working age benefit numbers in February 2012, by local authority (Source: DWP)

- Housing Benefit loss allocated on basis of estimated expenditure on claimants in the private rented sector, by local authority, derived from overall Housing Benefit expenditure data for 2011/12 and share of claimants in the private rented sector in August 2012 (Sources: DWP) 


\section{Sheffield Hallam University}

Hitting the poorest places hardest : the local and regional impact of welfare reform

BEATTY, Christina <http://orcid.org/0000-0003-0943-9979> and FOTHERGILL, Stephen $<$ http://orcid.org/0000-0002-4201-0640>

Available from the Sheffield Hallam University Research Archive (SHURA) at:

http://shura.shu.ac.uk/15884/

\section{Copyright and re-use policy}

Please visit http://shura.shu.ac.uk/15884/ and http://shura.shu.ac.uk/information.html for further details about copyright and re-use permissions. 